\section{Hydrocarbon plumbing systems of salt minibasins offshore Angola revealed by three-dimensional seismic analysis}

\author{
Katrine J. Andresen, Mads Huuse, Niels H. Schødt, \\ Lene F. Clausen, and Lars Seidler
}

\section{ABSTRACT}

Analysis of three-dimensional seismic data from the lower Congo Basin, offshore Angola, reveals numerous fluid-flow features in the Miocene to Holocene succession and the potential for large, shielded traps underneath basinward overhanging salt structures. The fluid-flow evidence includes present-day sea floor pockmarks clustered above salt structures, PliocenePleistocene stacked paleopockmarks and Miocene pockmark fields. Other fluid-flow features include high-amplitude cylindrical pipe structures 60 to $300 \mathrm{~m}(197-984 \mathrm{ft})$ wide and 25 to $300 \mathrm{~m}(82-984 \mathrm{ft})$ high within lower and middle Miocene strata, thick $(<150 \mathrm{~m}[492 \mathrm{ft}])$ high-reflectivity zones within the Pliocene succession associated with bottom-simulating reflections, and subvertical low-amplitude chimneys originating from the deeper section ( $>1 \mathrm{~km}[0.6 \mathrm{mi}]$ beneath the sea floor). The Miocene pockmark fields occur at a specific horizon, suggesting a regional fluid expulsion event at ca. $12 \mathrm{Ma}$, and the Miocene fluid-flow regime is interpreted to be dominated by thermogenic fluids supplied via carrier beds and leaking vertically above structural highs. The Pliocene-Pleistocene fluidflow regime was dominated by short-distance vertical fluid migration and expulsion related to early stage diagenetic processes involving biogenic methane and pore water. The present-day fluid-flow regime is inferred to be dominated by thermogenic fluids primarily controlled by kilometer-scale salt-flankcontrolled migration.

The study emphasizes the use of seismically imaged fluidflow features in hydrocarbon systems analysis by documenting

Copyright (C)2011. The American Association of Petroleum Geologists. All rights reserved.

Manuscript received March 19, 2010; provisional acceptance July 28, 2010; revised manuscript received October 31, 2010; final acceptance December 13, 2010.

DOl:10.1306/12131010046

\section{AUTHORS}

KATRINE J. ANDRESEN $\sim$ Department of Earth Sciences, Aarhus University, Høegh-Guldbergs Gade 2, 8000 Århus C, Denmark; katrine.andresen@geo.au.dk

Katrine Juul Andresen has B.Sc. (2004) and M.Sc. (2007) degrees in geology (Aarhus University) and is currently finishing her Ph.D. studies at Aarhus University, dealing with the 3-D seismic expression of fluid-flow features that originated in hydrocarbon plumbing systems in the North Sea and the Angola Basin, including a description of elongated and stacked paleopockmarks and sand and chalk remobilization.

MADS HuUSE $\sim$ School of Earth, Atmospheric and Environmental Sciences, University of Manchester, Williamson Building, Oxford Road, Manchester, M13 9PL, England;

mads.huuse@manchester.ac.uk

Mads Huuse is a reader in geophysics at the University of Manchester. After a Ph.D. from Aarhus University (1999), he undertook postdoctoral research at Aarhus, Aberdeen, and Cardiff, focusing on basin analysis, sediment remobilization, and fluid flow, before taking up a lectureship at the University of Aberdeen. His interests include the seismic interpretation of basins, their evolution, structures, depositional elements, reservoirs, seals, and fluids.

Niels H. SCHøDT $\sim$ Exploration Department, Maersk Oil, Esplanaden 50, 1263 Copenhagen K, Denmark; niels.schoedt@maerskoil.com

Niels Schødt is a team lead for Angola Regional Studies and New Ventures at Maersk Oil in Copenhagen. He has an M.Sc. degree in geology (Aarhus University) and has worked in the oil industry since 1989. He started at Schlumberger as a wireline engineer and since 1996 has worked in exploration projects in Maersk Oil, primarily focusing on seismic interpretation.

LENE F. CLAUSEN $\sim$ Exploration Department, Maersk Oil, Esplanaden 50, 1263 Copenhagen K, Denmark; lene.clausen@maerskoil.com

Lene F. Clausen is head of the New Ventures Study Teams in Exploration, Maersk Oil, Copenhagen. She has worked with exploration since 1998 mainly in the North and South Atlantic. She received a graduate diploma in geology 
in 1991 (Australian National University, Canberra), M.Sc. degree in 1993, and a Ph.D. in 1997 (University of Copenhagen).

LARS SEIDLER Maersk Oil Houston Inc., 2500 City West Boulevard, Suite 2500, Houston, Texas 77042; lars.seidler@maerskoil.com

Lars Seidler is a project manager for the Angolan Chissonga Development at Maersk Oil Houston. Seidler has worked in upstream research, development, and production, starting with ExxonMobil in 2000. Since 2006, he has worked in exploration and development with Maersk Oil. He received a Ph.D. in geology in 1999 (University of Copenhagen).

\section{ACKNOWLEDGEMENTS}

Maersk Oil and partner Sonangol are thanked for providing the seismic data and the stratigraphy for the study and allowing us to publish the data. The main seismic interpretation was conducted by K. J. Andresen at an internship at Maersk Oil Copenhagen and during two student visits at the University of Aberdeen. Landmark and Seismic Micro Technology are thanked for granting university licenses for the University of Aberdeen. Aarhus University, the Faculty of Science, is thanked for sponsoring the Ph.D. of $\mathrm{K}$. J. Andresen. The editor and the three reviewers, Ian Davison, Robert Ehrlich, and Alexander Kitchka, are thanked for their comments, ideas, and suggestions.

The AAPG Editor thanks the following reviewers for their work on this paper: Ian Davison, Robert Ehrlich, and Alexander A. Kitchka. the evolution of an overburden plumbing system through time, involving several fluid types and flow regimes, depending on the spatiotemporal availability of thermogenic and diagenetic fluids and the tectonostratigraphic occurrence of aquifers, traps, and seals.

\section{INTRODUCTION}

Fluid-flow features such as pockmarks and clastic injections have gained increasing attention during recent years, particularly because of their use in hydrocarbon exploration and production and because of the high-resolution degree of detail, coverage, and high quality of three-dimensional (3-D) seismic surveys now available (Davies et al., 2004; Berndt, 2005; Cartwright and Huuse, 2005; Cartwright et al., 2007; Gay et al., 2007; Løseth et al., 2009; Huuse et al., 2010). Importantly, this has increased the success of detecting and recognizing fluidflow features in the first place. Fluid-flow features arise when fluids (including diagenetic and magmatic fluids) are expelled from depth and migrate through the overburden to the surface (Cartwright et al., 2007). Of particular economic interest is the expulsion of hydrocarbons from mature source rocks and their migration, storage, and remigration (leakage) through the overburden toward the free surface (Heggland, 1997; O'Brien et al., 2005; Cartwright et al., 2007). During migration, some of the fluids will be trapped in reservoirs or temporary compartments, whereas others during their path to the surface permanently will imprint and mark the stratigraphic succession (Magoon and Dow, 1994; Cartwright et al., 2007). Examples of fluid-flow features and their seismic expression include pockmarks; amplitude anomalies of varying expressions, including gas and oil accumulations; bottom-simulating reflections (BSRs) and hydrocarbon-related diagenetic zones, pipes, chimneys, and acoustic distortions (velocity effects and wipeout zones); and injections of mud and sand (Cowley and O'Brien, 2000; Cartwright et al., 2007; Judd and Hovland, 2007; Andresen et al., 2008; Løseth et al., 2009; Huuse et al. 2010). The different types of fluid-flow features will ideally imprint the sediments in different styles and careful investigation and interpretation of such features may thus help distinguish between different fluid-flow origins (i.e., thermogenic, biogenic, or nonhydrocarbon diagenetic fluids). Fluid-flow features can be used directly in basin analysis of active hydrocarbon systems to reveal the fluid-flow history, timing, and migration, with emphasis on reservoir and seal analysis. 


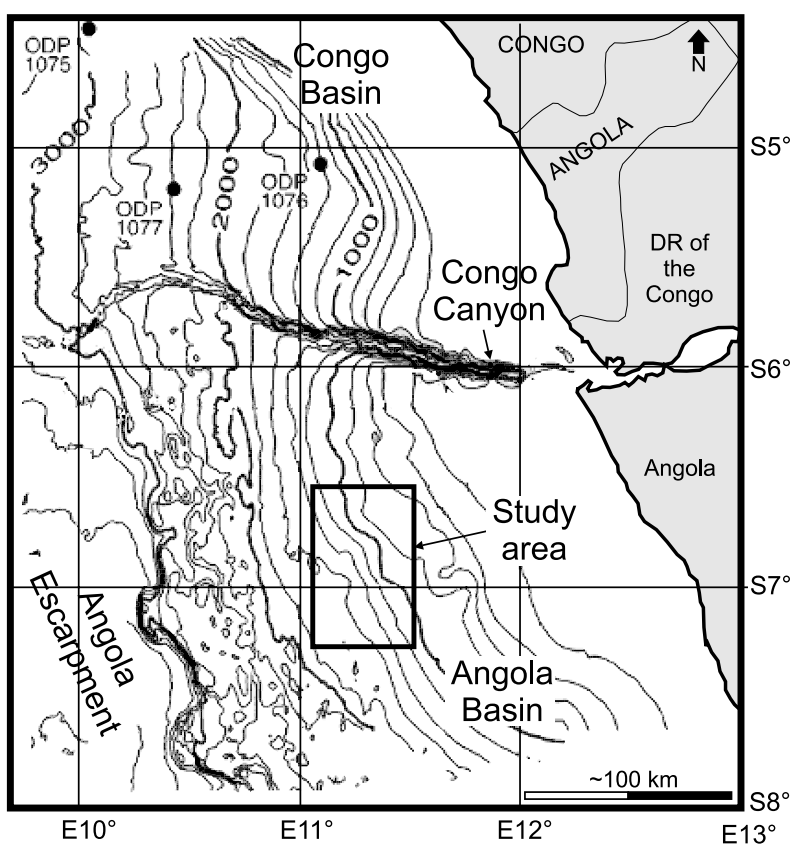

Figure 1. Map of the lower Congo Basin with the Congo (Zaire) submarine canyon system and the location of the study area offshore Angola. Seabed contours show the gradual westwarddipping topography. Modified from Gay et al. (2006a).

This study describes several fluid-flow features within the overburden succession (Miocene to Holocene) offshore Angola (Figure 1). The different types of fluid-flow features typically occur in different stratigraphic intervals, and hence the study area represents a unique possibility of deciphering the fluid migration history by debating the origin and interpretation of the fluid-flow features in relation to a description of the hydrocarbon plumbing system and fluid-flow regimes from the Miocene to the present time. Some of the fluid-flow features furthermore suggest a more regional timing of the initial fluid migration to the sea floor at the middle Miocene, whereas others possibly can be seen as indicators of large shielded traps beneath salt overhangs, where direct seismic imaging of hydrocarbon presence may be difficult.

\section{DATABASE}

The study was conducted primarily by the use of two smaller subsets of a regional 3-D seismic vol- ume acquired offshore Angola, focusing on two adjacent salt minibasins of an approximately $300 \mathrm{~km}^{2}$ $\left(\sim 116 \mathrm{mi}^{2}\right)$ area (Figure 2), which exhibit many similarities with other minibasins in the area. Three seismic volumes were available for the study: a near stack volume, a far stack volume, and a coherency volume. The primary volume for reference is the near stack volume, where acoustic impedance increases ("hard" reflections) are indicated by negative amplitudes illustrated as white, red, or orange troughs, depending on the color bar used in the specific seismic data displays used in this article. Bin spacing is $12.5 \mathrm{~m} \mathrm{(4l} \mathrm{ft)} \mathrm{in} \mathrm{both} \mathrm{directions.} \mathrm{The}$ focus of this study has been the overburden succession (Miocene-Holocene) in the two salt minibasins above the prospective Oligocene turbiditic interval and data down to approximately $4 \mathrm{~s}$ twoway traveltime (TWT) were analyzed in detail. The typical resolution in the seismic data set is about 5 to

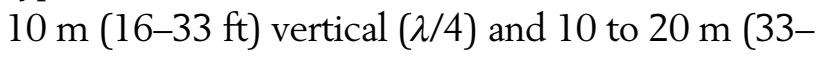
$66 \mathrm{ft}$ ) horizontal $(\lambda / 2)$ when assuming an average seismic interval velocity of $1680 \mathrm{~m} / \mathrm{s}(5512 \mathrm{ft} / \mathrm{s})$ for the entire Miocene to Holocene overburden (Bolli et al., 1978). Well data were not available for the fluid-flow features reported herein and thus not used directly in this study but stratigraphic picks in nearby exploration boreholes, and far-field oceandrilling program (ODP) boreholes formed the basis for age calibrations of key horizons within the seismic-stratigraphic framework (Figure 3).

\section{METHODOLOGY}

The workflow for the detection and analysis of the shallow seismic fluid-flow features used in this study (Figure 4) involved a systematic examination of the seismic data for any anomalies (amplitude or morphological), primarily by analysis of the vertical seismic sections, time slices, TWT thickness maps and amplitude, TWT structure and coherency maps of horizons, intervals, and isoproportional slices, subdividing each seismic stratigraphic unit into several subunits. Long- and short-window volume attribute extractions (typically root mean square [RMS] amplitude and coherency) were critical for 
Figure 2. Relative position of the two three-dimensional seismic subsets used in this study, showing seabed coherency $(A)$ and seabed azimuth dip (B). The main structural elements such as salt structures, rafts, and faults have been indicated. Seabed pockmarks mostly concentrated at salt structures, and the characteristic seabed furrows can be seen. Also indicated are the extent of the middle Miocene pockmark fields (Figure 8) and the stacked paleopockmarks (Figure 9).

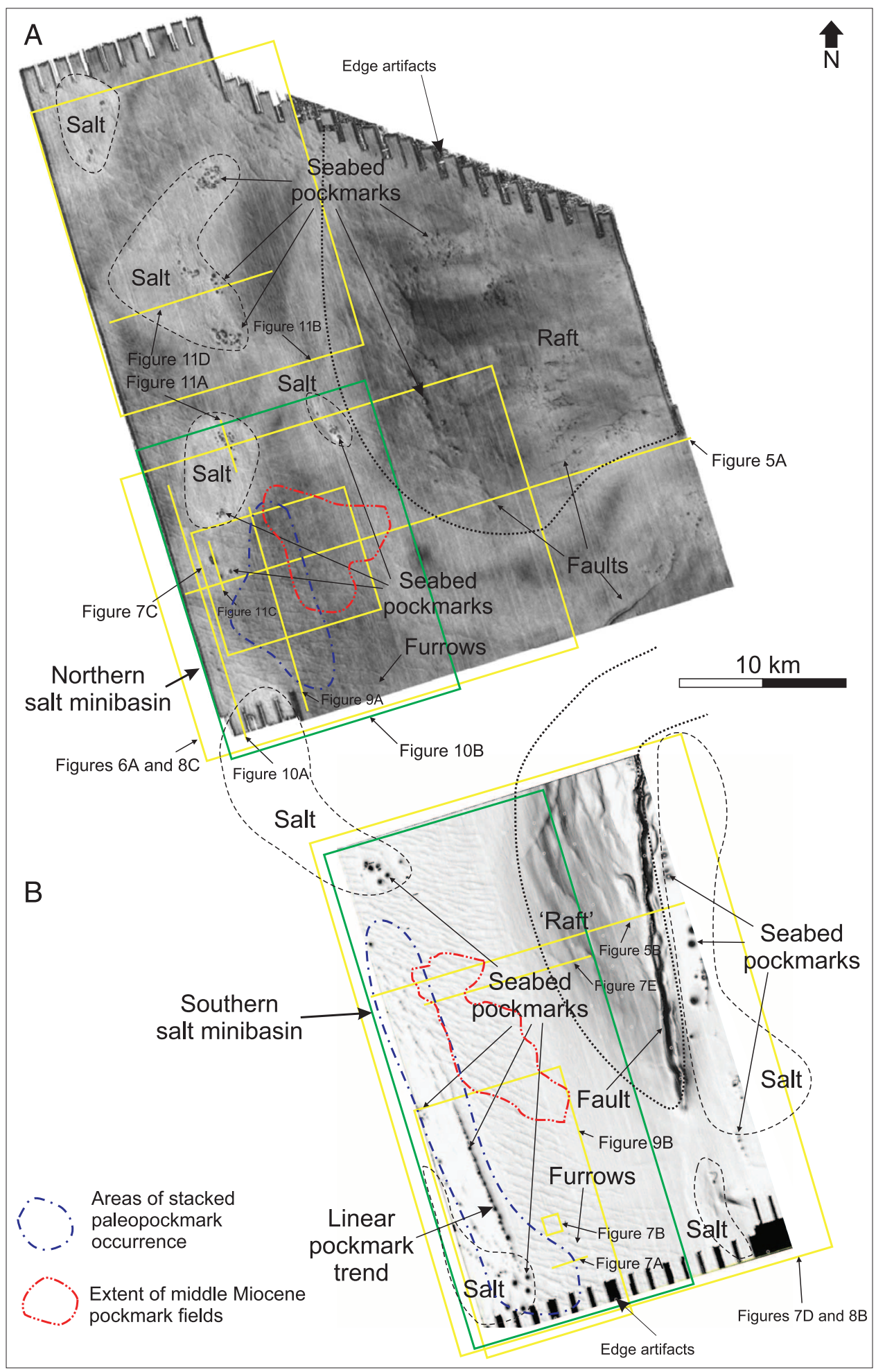

the detection of the fluid-flow features, and surface attribute extractions of both picked horizons and derivative isoproportional horizons added stratigraphic detail in an efficient manner. Isoproportional horizon calculations were based on smoothed and filtered bounding key horizons (Figure 5), thus maximizing the stratigraphic information gained simply by filtering out small-scale variations only present on the individual surface, attributable to local offsets, depositional or erosional features, or 


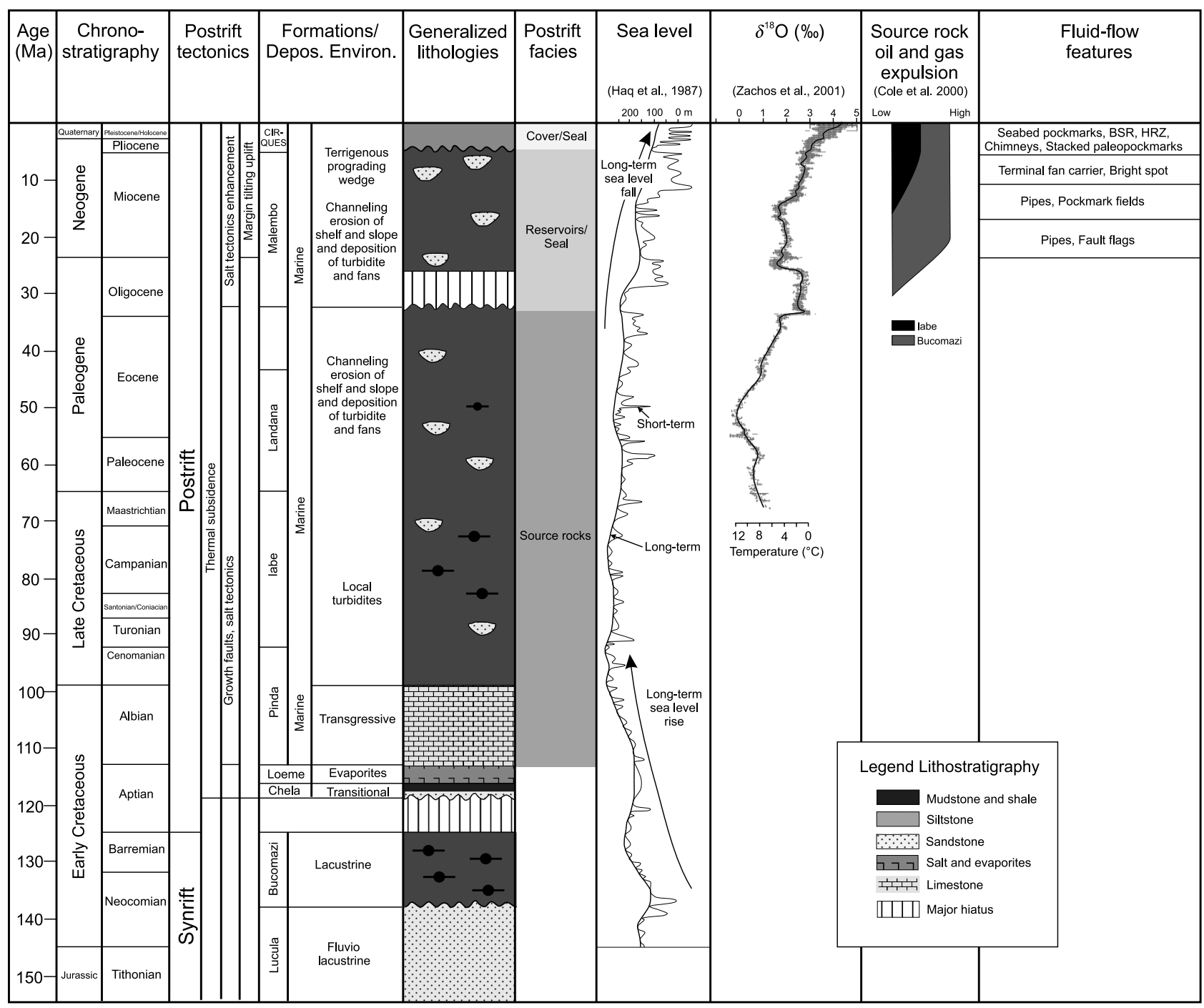

Figure 3. Seismic-stratigraphic framework of the lower Congo Basin and the study area. Compiled and modified from Haq et al. (1987), Burwood et al. (1990), Seranne (1999), Valle et al. (2001), Zachos et al. (2001), Broucke et al. (2004), Anka et al. (2009). BSR= bottom-simulating reflection; HRZ = high-reflectivity zone.

errors unique to the bounding surface. An adequate number of isoproportional horizons were calculated to slice up the seismic data volume in proportional relevant intervals varying with the intensity of fluid-flow features. The intervals were chosen such that the maximum spacing between isoproportional horizons did not exceed approximately $100 \mathrm{~ms}$ TWT in successions with a small number of fluid-flow features and approximately $50 \mathrm{~ms}$ TWT in successions with abundant fluidflow features (Figure 5).

Each horizon attribute map was carefully examined for potential fluid-flow anomalies, which are most conspicuous when expressed as amplitude or coherency anomalies, and further manual and automated picking of selected anomalies was conducted. The anomalies were then further crossreferenced against their seismic expression in vertical and horizontal seismic sections to classify the anomalies into different types and discriminate real fluid-flow anomalies from overburden effects distorting the underlying seismic image.

Well-log data were only used indirectly to assign ages and sedimentation rates as none of the available wells intersect any of the fluid-flow features detected in this study. Compared with the 
Figure 4. Workflow for the detection and classification of the fluid-flow features in the study area. RMS = root mean square.

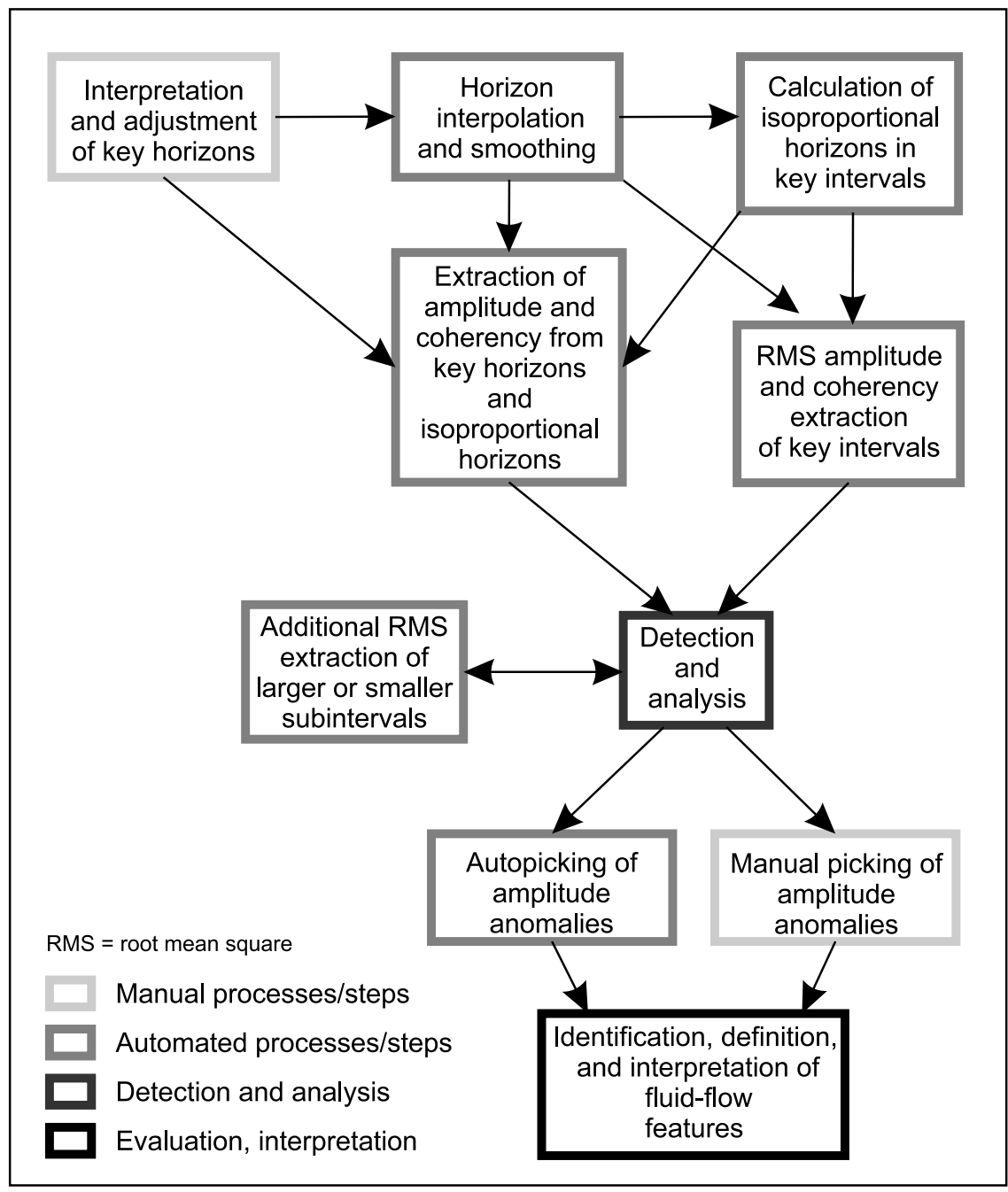

vast coverage and use of the $3-\mathrm{D}$ seismic data in the detection of fluid-flow features, the chance of a direct borehole hit through a fluid-flow feature is very small, particularly because any detected fluidflow features are commonly avoided in well planning stages. However, iflogged or cored directly, for example, in site survey or integrated ocean-drilling program (IODP) investigations, the true nature of the fluid-flow feature and the fluids responsible for generating the feature could be revealed. This would substantially add to the understanding of the fluidflow features, which are typically only detected remotely using seismic data (Cartwright et al., 2007; Gay et al., 2007).

Because of the higher resolution, the near stack seismic volume has been the primary tool for detecting the fluid-flow features. The far stack vol- ume was, however, useful for the evaluation of the fluid content in the amplitude anomalies because anomalies also appearing in the far stack volume tend to be stronger because of the higher elastic impedance contrast of gas- and oil-filled shallow sands predicted by standard amplitude versus offset (AVO) analysis (Ostrander, 1984; Rutherford and Williams, 1989; Bacon et al., 2003). A careful comparison of the imprint of a fluid-flow feature on both near and far stack seismic volumes is thus a useful fluid discriminator in the interpretation of shallow fluid-flow features, although subject to the usual problems of estimating fluid saturations because of the nonlinear velocity change with low-saturation increases in the gas content of unconsolidated porous media. Other remote-sensing geophysical techniques such as gravity data and 

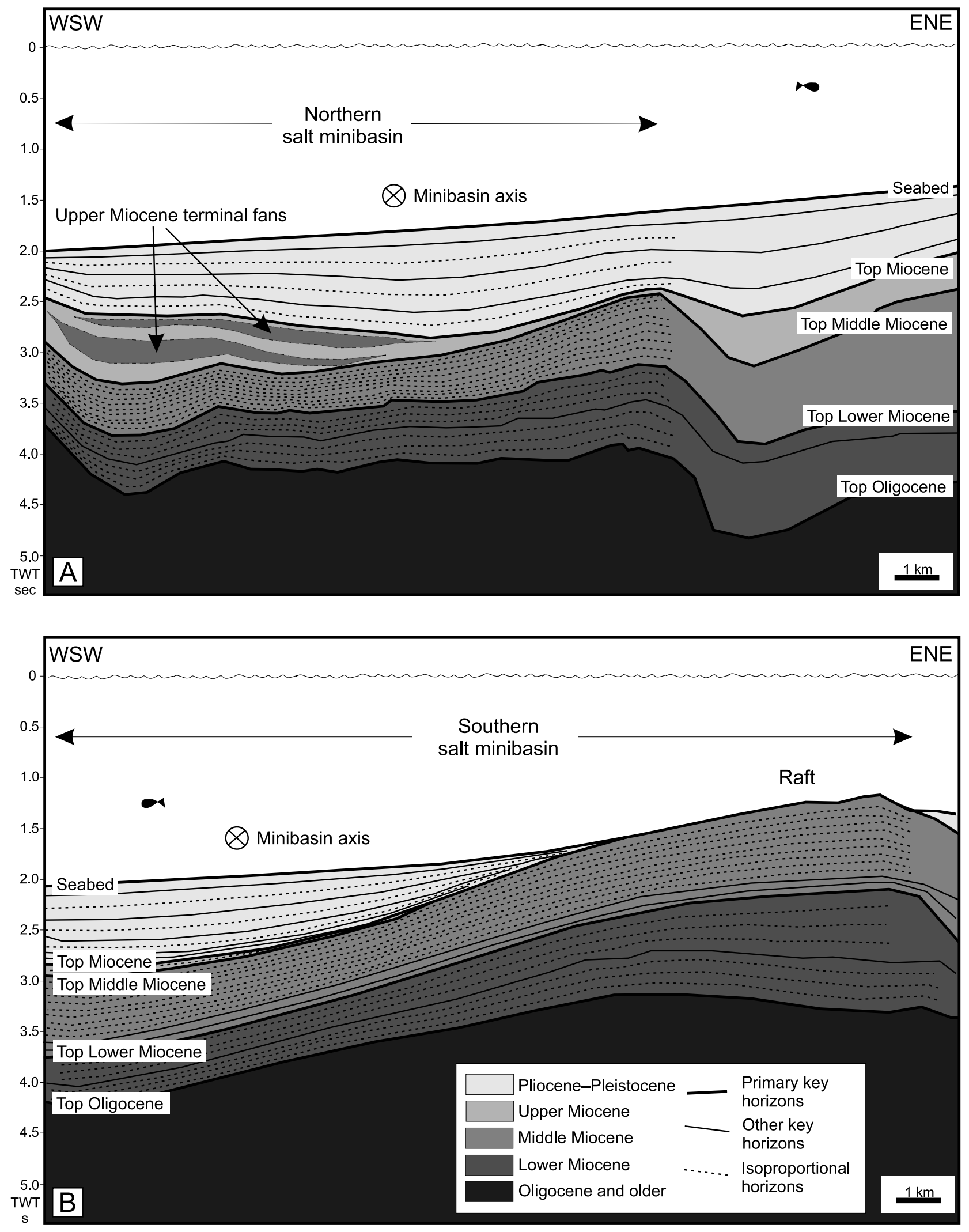

Figure 5. Geoseismic sections perpendicular to the minibasin axes from the northern (A) and southern (B) salt minibasins, illustrating the main arrangement of Miocene to recent strata along with the key horizons and isoproportional horizons used in the study. The slope direction is to the southwest. See Figure 2 for the approximate position of geoseismic sections. TWT = two-way traveltime. 
controlled source electromagnetic data (Hesthammer et al., 2010) may possibly be used to shed further light on the fluid content of the anomalies detected in this and other studies of shallow fluidflow features.

\section{GEOLOGIC SETTING}

The study area is located offshore Angola in the lower Congo Basin at 1 to $1.5 \mathrm{~km}(3300-5000 \mathrm{ft})$ water depth (Figures 1, 5). The lower Congo Basin along with several other major subbasins in the passive continental margin of west Africa was generated during the Early Cretaceous as a response to the opening of the South Atlantic Ocean (Brice et al., 1982; Marton et al., 2000). The main source rock for the lower Congo Basin is constituted by the bituminous shales of the Lower Cretaceous Bucomazi Formation deposited during the rift phase (Burwood, 1999; Cole et al., 2000), which expelled oil and gas from the early Miocene onward (Cole et al. 2000) (Figure 3). After the rift phase, a thick (>1 km [>3300 ft]) evaporite accumulation, the Loeme Formation, was deposited (Figure 3) (Brice et al., 1982; Uchupi, 1992), which facilitated later gravitational sliding of the postrift sequence, by acting as a decollement layer, resulting in the formation of numerous salt structures and salt minibasins (Duval et al., 1992; Lundin, 1992; Liro and Coen, 1995; Valle et al., 2001; Fort et al., 2004). The postrift sequence is thus divided into an upper slope extensional domain characterized by grabens and rafts and a downslope compressive domain characterized by salt diapirs, canopies, and walls (Lundin, 1992; Marton et al., 2000; Rouby et al., 2002). The study area is located at the transition between the two domains, thus containing grabens, rafts, salt diapirs, including some diapirs with overhangs, and intervening minibasins (Figures 2, 5).

An Oligocene unconformity separates the postrift Cenozoic sediments into two major units (Figure 3) (Seranne et al., 1992; Seranne, 1999). A stable climate with low-amplitude high-frequency sea level changes (greenhouse period) characterized the late Early Cretaceous to early Oligocene interval and resulted in the development of an aggradational carbonate-siliciclastic ramp architecture (Seranne, 1999) (Figure 3). Source rock potential from the postrift period is generally found within the Upper Cretaceous Iabe Formation and the $\mathrm{Pa}$ leogene Landana Formation (Burwood, 1999; Cole et al., 2000), which have been mature for oil and gas generation since about the mid-Miocene (Cole et al., 2000) (Figure 3). The hydrocarbon generation potential would thus suggest a great potential for focused fluid-flow conduits within the area (cf. Gay et al., 2006a; Cartwright et al., 2007).

The early Oligocene to Holocene interval (icehouse period) is characterized by an overall regression superimposed by high-amplitude and highfrequency sea level fluctuations (Figure 3) (Bartek et al., 1991; Seranne, 1999) and climate altering between dry and wet. During this interval, a large terrigenous wedge prograded into the basin, accompanied by deep incision and erosion of the Congo (Zaire) submarine canyon (Seranne, 1999). Oligocene and Miocene turbidite fan systems were deposited in the lower Congo Basin (Droz et al., 1996; Sikkema and Wojcik, 2000; Broucke et al., 2004) and now host a large proportion of the significant oil and gas discoveries found in the area during the last decade (Burwood, 1999; Cole et al., 2000; Gay et al., 2006b; Liu et al., 2008). The marked increase of the clastic input to the continental slope has variously been linked to Miocene uplift of the African continent (Brice et al., 1982; Lavier et al., 2001) and climatic change (Bartek et al., 1991), which, along with the distribution of salt structures, controlled the position of the turbiditic submarine flows (Sikkema and Wojcik, 2000; Broucke et al., 2004). From the early Pliocene to the present day, the coarse fraction of the sedimentation was captured by the Congo Canyon, and the lower Congo Basin thus only received sparse amounts of fine-grained sediments along with pelagic production, resulting in mostly hemipelagic and pelagic sedimentation (Jansen et al., 1984; Pufahl et al., 1998; Uenzelmann-Neben, 1998). The Pliocene to Holocenesuccession, along with the predominant mudstone intervals of the OligoceneMiocene succession, is therefore commonly considered to be a seal to the Oligocene and Miocene 

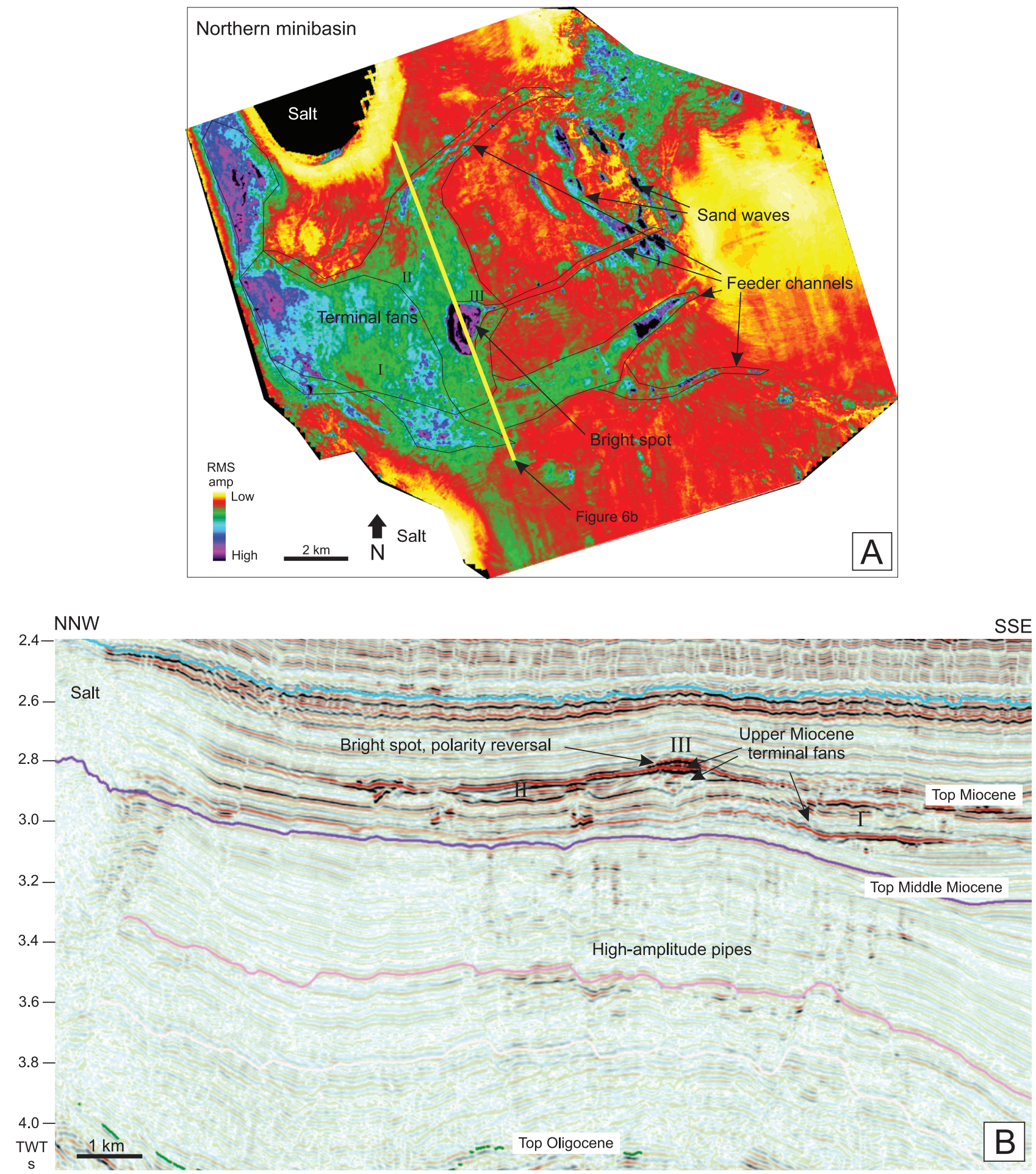

Figure 6. (A) The system of three upper Miocene terminal fans and associated feeder channels. The fans are deposited in the minibasin low between two salt structures, while the channels are incised at paleohigh areas. (B) The smallest and upper terminal fan is associated with a bright spot and a polarity reversal. Also seen are several high-amplitude pipes in the middle Miocene section below the terminal fans. RMS = root mean square.

turbiditic intervals (Burwood et al., 1990; Gay et al., 2007; Liu et al., 2008). In the lower Congo Basin, the Pliocene-Pleistocene succession is furthermore affected by polygonal faulting, which has previously been linked with the formation of seabed pockmarks and characteristic seabed furrows that are 


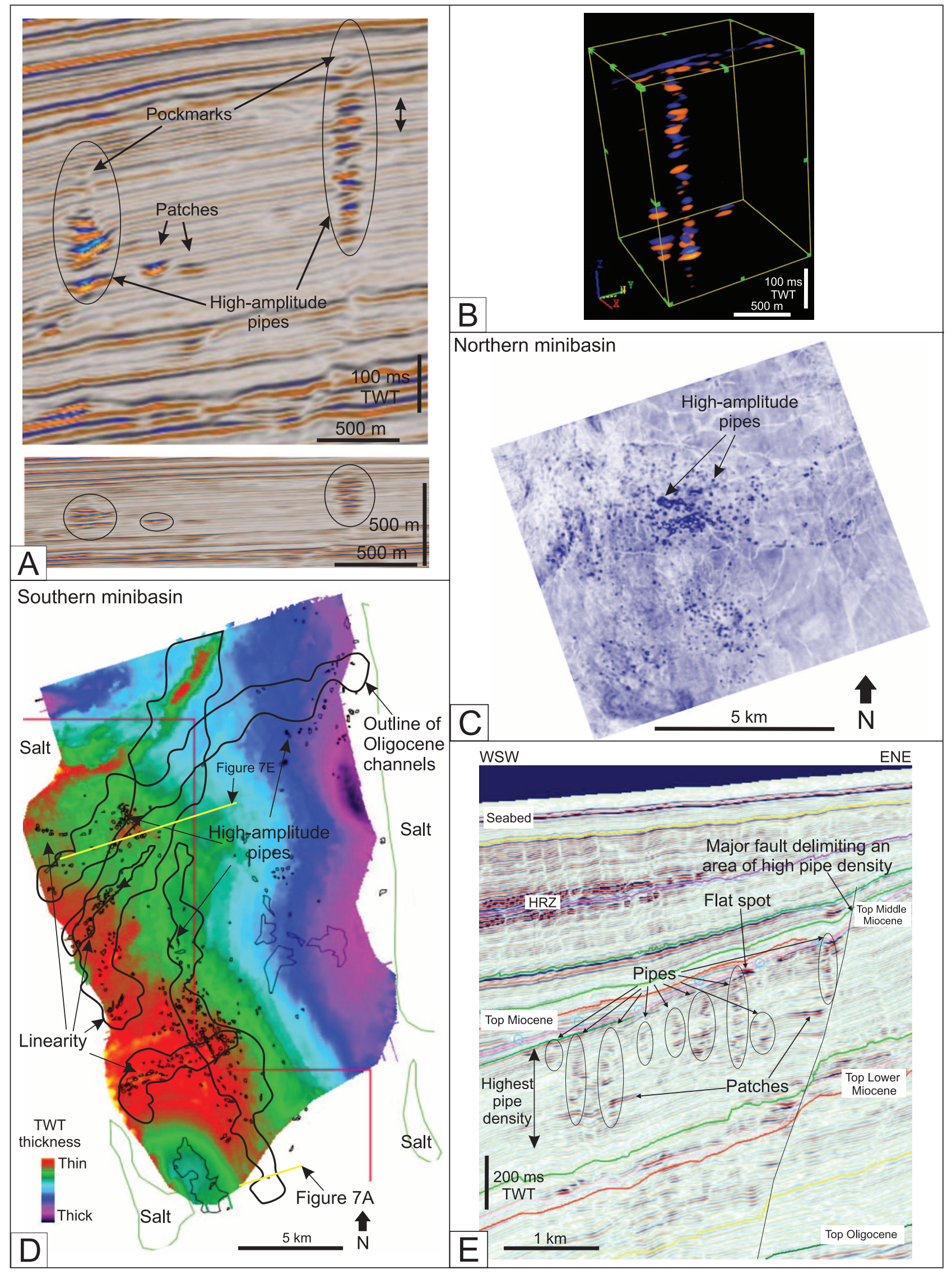




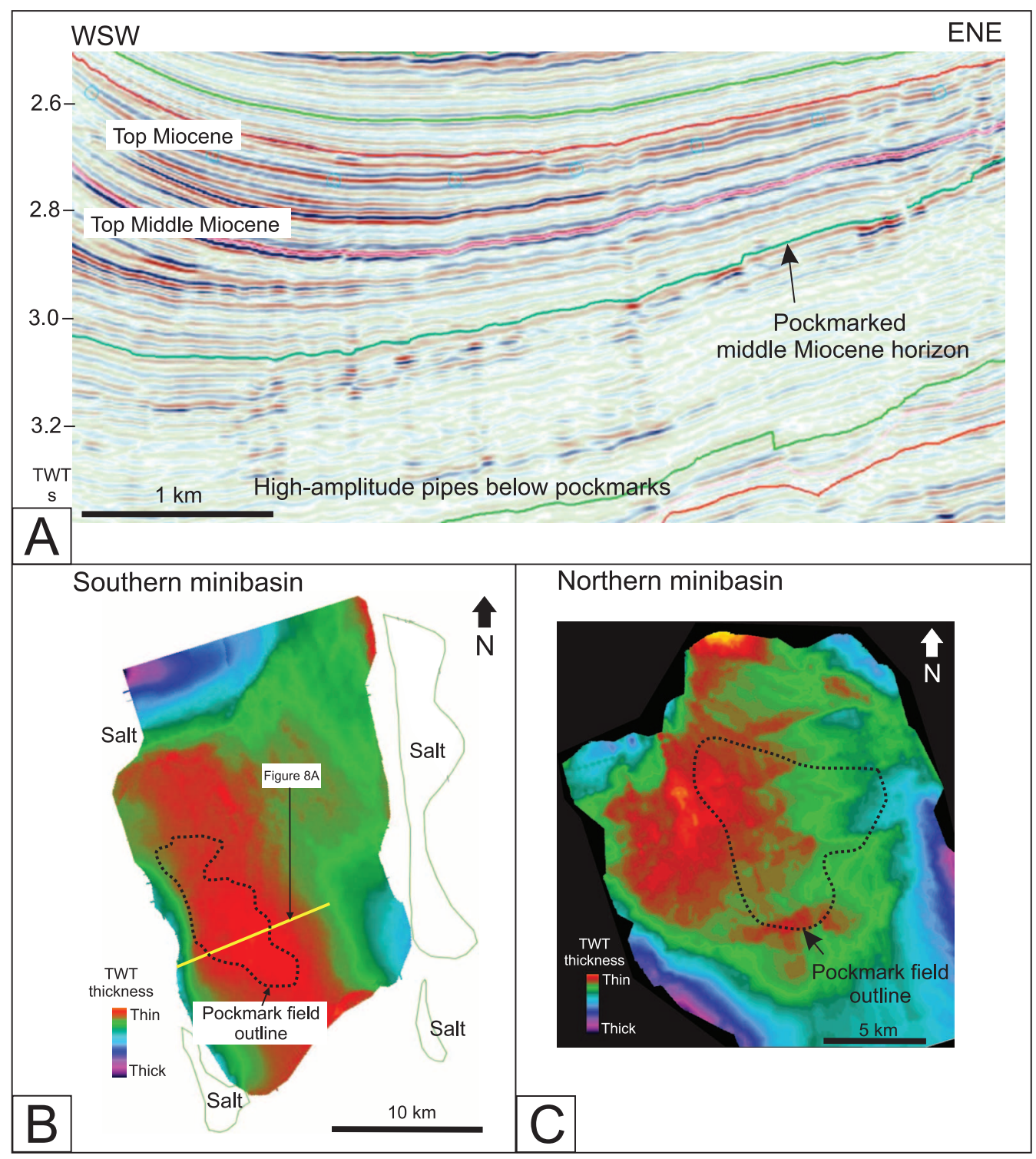

Figure 8. (A) Seismic section showing the upper middle Miocene pockmark field (ca. $12 \mathrm{Ma}$ ). The pockmarks are typically underlain by highamplitude pipes. The twoway traveltime (TWT) thickness map of the middle Miocene succession in the southern (B) and northern (C) minibasins illustrates how the pockmark fields are generally found above syndepositional highs.

ubiquitous in the deep-water offshore Angola (Gay et al., 2004). However, in some cases, the polygonal faults appear to postdate the earliest phase of fluid expulsion and pockmark formation (Andresen and Huuse, 2011).

\section{KEY SEISMIC OBSERVATIONS}

The overburden of the study area is composed of a 1- to 2-km (0.62-1.25-mi)-thick Miocene to Holocene succession above the prospective Oligocene

Figure 7. (A) Seismic section with (top) and without (bottom) vertical exaggeration of approximately six times showing some typical high-amplitude pipes in the middle Miocene succession. Blue colors indicate positive amplitudes and soft reflection events. (B) Amplitude rendering highlights one pipe, illustrating the cylindrical appearance (here with vertical exaggeration) common to most of the pipes. (C) Root-mean-square amplitude extraction of the interval indicated by double arrows in (A) illustrating how the pipes show up as circular highlights. The highest concentrations of pipes are related to syndepositional highs, whereas the linearity in the east can be correlated to faults. (D) The two-way traveltime (TWT) thickness map of the lower Miocene with the high-amplitude pipes superimposed. There is a strong correlation between syndepositional highs and the concentrations of pipes. Furthermore, linear arrangements of the pipes in the western part of the area suggest a correlation to underlying Oligocene channels. (E) Seismic section showing how a major fault delimits an area of high pipe density in the updip direction. The section also illustrates how the density of the pipes varies stratigraphically with the highest density in the middle Miocene succession. HRZ $=$ high-reflectivity zone. 


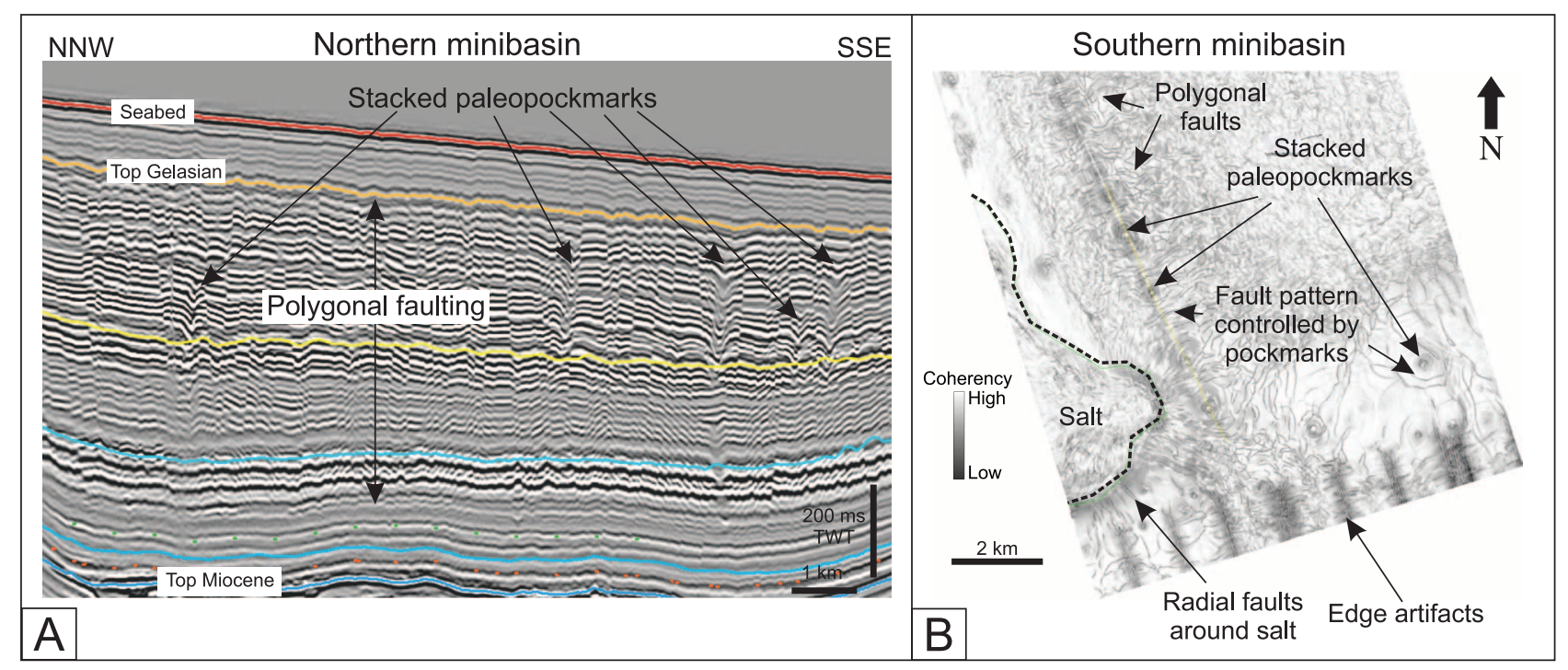

Figure 9. (A) Cross sectional expression of the stacked paleopockmarks from the northern minibasin showing five stacked paleopockmarks within the Pliocene-Pleistocene succession with varying vertical extents. (B) Plan view expression of the stacked paleopockmarks illustrated by a coherency display from the southern salt minibasin. The stacked paleopockmarks occur within polygonal fault cells.

turbiditic interval (Figure 5). A variety of fluid-flow features have been observed above the Oligocene, including pipelike, commonly cylindrical and isolated high-amplitude reflections; bright spots and polarity reversals; BSRs; and pockmarks (Figures 612). In this article, the key observations relevant for the fluid plumbing system in the study area will be addressed.

\section{Fluid-Flow Features in the Miocene Succession}

The Miocene succession comprises as much as $1.5 \mathrm{~km}$ $(\sim 5000 \mathrm{ft})$ of lower, middle, and upper Miocene sediments (Figure 5). Within this succession, fluidflow features commonly affect the stratal reflections, and seismic data reveal several kinds of fluid-flowrelated anomalies. Generally, most of the fluid-flow anomalies are observed in the thicker lower and middle Miocene successions, which are mainly composed of fine-grained mudstones occasionally interrupted by turbiditic intervals (Seranne et al., 1992; Anderson et al., 2000; Cole et al., 2000). In contrast, the thin upper Miocene succession is dominated by incised channels at paleohigh areas and large coarser grained terminal fan systems deposited in the bathymetrically deeper regions (salt minibasins) between salt structures against which the fans pinch out (Figure 6A). Direct hydrocarbon indicators such as bright spots and in some cases polarity reversals (depending on the lithology and porosity of the sediments above and below the fluid-gas contact; Bacon et al., 2003) are sporadically seen within the terminal fan and channel deposits, indicating that hydrocarbons (probably gas) are presently stored in these systems (Figure 6B). Apart from closures within the upper Miocene minibasin fans, channels, and associated deposits, fluid-flow anomalies are generally only sparsely observed in the upper Miocene succession.

\section{High-Amplitude Pipes}

The most dominant amplitude anomaly in the lower and middle Miocene successions is a feature that may occur as a single anomaly or more commonly contribute to a cylindrical pipelike arrangement of stacked segments of high-amplitude reflections of varying vertical (30-350 ms TWT, 25-300 m [82-985 ft]) and lateral extent (60-300 m [196$985 \mathrm{ft}]$; Figures 6B; 7A, B). Both positive and negative amplitudes are elevated within the pipes, and the upward termination of the pipes likewise 



Figure 10. (A) Seismic section above the distal part of the upper Miocene terminal fan system in the northern salt minibasin showing two high-reflectivity zones (HRZs). The HRZs might be related to fluids leaking out of the fans or from the anticline. The HRZs terminate abruptly at discrete polygonal fault planes. Note that chimneys bypass the gas-hydrate stability zone both at the salt structure and above the HRZ overlying a deeper Miocene structure. (B) Root-mean-square (RMS) amplitude extraction of the Pliocene-Pleistocene succession clearly showing the distribution and extent of the HRZs in the northern salt minibasin. Also shown are the extent of the stacked paleopockmarks, the middle Miocene pockmark field, and the upper Miocene terminal fan systems.

differs between peaks and troughs. In some subareas, a tendency toward a peak (positive amplitude) reflection at the top is indicative of a soft reflection from the pipe and a decrease in acoustic impedance. The vertical extent of the pipes varies with the number of amplitude-elevated peaks and 


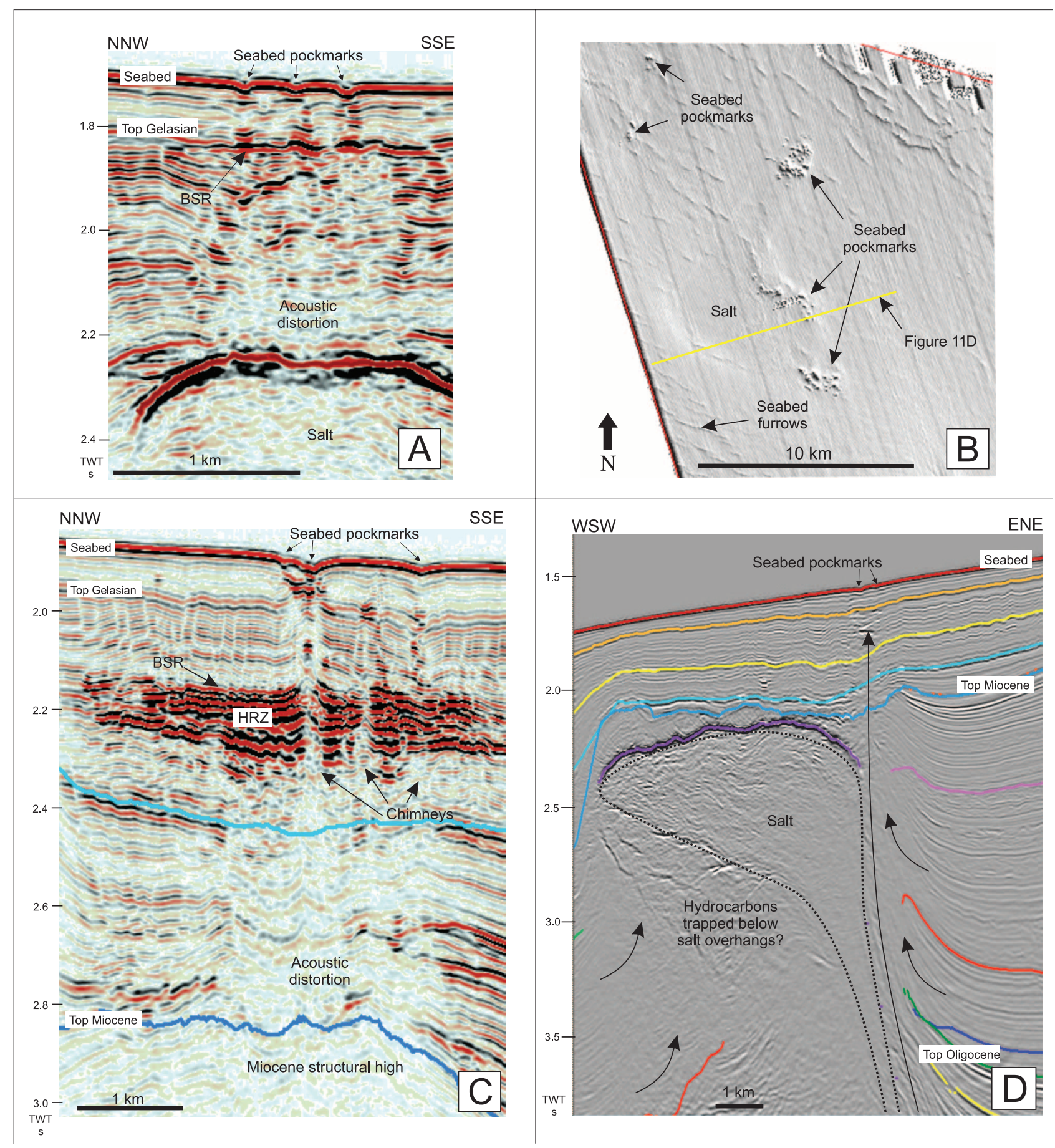

Figure 11. (A) Seabed pockmarks above a salt structure. Below the pockmarks is a shallow bottom-simulating reflector (BSR) (100 m [330 ft] subseabed) and a wide zone of acoustic distortion. (B) Seabed dip map across a large overhanging salt structure showing the pockmark clusters at the updip side of the salt. (C) Seabed pockmarks associated with deeply rooted seismic chimneys emanating from a Miocene structural high. The lower parts of the chimneys are represented by acoustic distortion. A BSR is located 230 ms two-way traveltime (TWT) below the seabed and underlain by a 175-ms thick high-reflectivity zone (HRZ). The chimneys bypass the HRZ and the gas-hydrate stability zone. (D) Seismic section illustrating the consistent updip occurrence of seabed pockmarks with respect to downdip overhanging salt structures, whereas pockmarks are absent from the downdip parts, possibly implying that hydrocarbons may be trapped below salt overhangs at the present day. Black arrows indicate likely fluid migration pathways. 


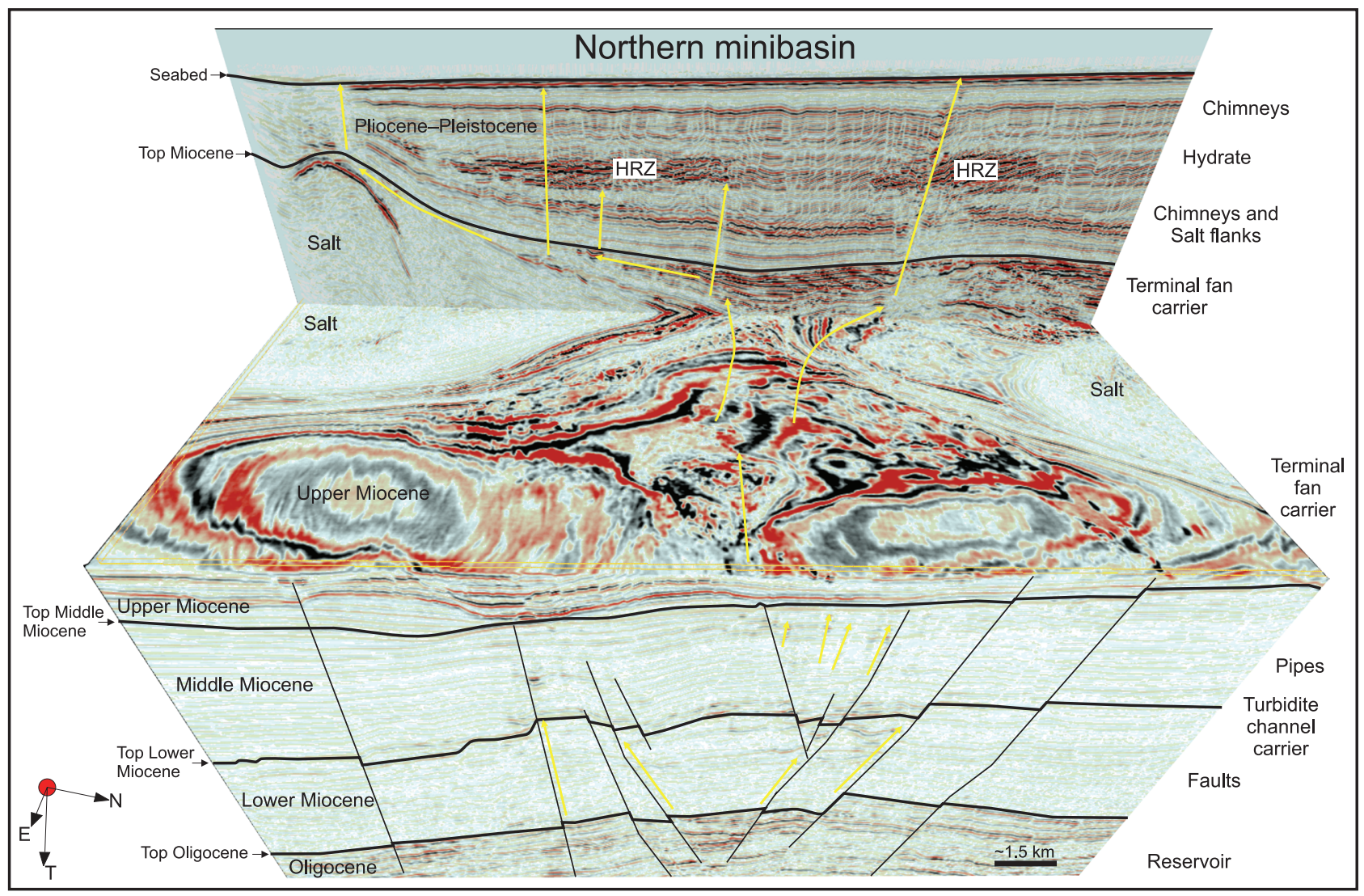

Figure 12. Chair display from the northern minibasin viewing toward the west (downdip). The three-dimensional constellation of vertical and lateral migration of deeply sourced fluids from reservoir to the surface is illustrated. Migration pathways change stratigraphically, varying through faults, Miocene carriers, salt flanks, and chimneys. HRZ = high-reflectivity zone.

troughs. The shortest amplitude anomalies thus only consist of one high-amplitude peak and one trough $(\sim 30 \mathrm{~ms}$ TWT or $25 \mathrm{~m}[82 \mathrm{ft}])$ and may thus be more aptly described as patches because they are more laterally than vertically extensive, even with the vertical exaggeration commonly applied to seismic data (typically 5-6 times) (see Figure 7A, E). The tallest pipes consist of 25 peaks and troughs comprised within an interval of approximately $350 \mathrm{~ms}$ TWT $(\sim 300 \mathrm{~m}[\sim 985 \mathrm{ft}])$ and hence display a larger vertical than lateral extent, thereby giving the cylindrical pipe geometry, even without vertical exaggeration (Figure 7A, E). Most of the pipes are cylindrical in geometry and hence appear as circular highlights in strata-parallel amplitude displays or time slices (Figure 7C). Paleopockmarks are sometimes observed at the upward termination of the pipes (Figures 7A; 8A) but typically the pipes terminate blindly without a paleosurface manifestation. Stratigraphically, the pipes generally occur throughout the whole Miocene succession, with the highest density in the middle Miocene strata, less pronounced density in the lower Miocene strata, and very sparse occurrences in the upper Miocene strata (Figure 7E). The pipe density furthermore increases in areas underlain by syndepositional structural highs (Figure 7D), and occasionally linearly arranged clusters are seen directly above deeper Oligocene channels (Figure 7D). Fault trends within the Miocene succession are occasionally highlighted by fault flags, and faults are furthermore seen to separate areas of high and low pipe density (Figure 7C, E).

\section{Organized and Dispersed Paleopockmarks}

Another key observation from the Miocene succession is the occurrence of two middle Miocene pockmark fields (Figure 8). The pockmark fields are found in the two separate salt minibasins, 10 to 
$15 \mathrm{~km}(\sim 6-9 \mathrm{mi})$ apart (Figure 2) at one specific horizon dated as ca. $12 \mathrm{Ma}$ (Maersk Oil, 2007, internal data). The pockmark fields have moderate extents in both minibasins (40-50 $\mathrm{km}^{2}$ [15-19 $\left.\mathrm{mi}^{2}\right]$ ) (with a pockmark density of approximately $3 / \mathrm{km}^{2}$ $\left(\sim 9 / \mathrm{mi}^{2}\right)$, and both fields are located above the crests of central syndepositional highs (Figure 8B, C) corresponding to the central parts of the presentday depocenters. The pockmarks in the fields are recognized as subtle circular depressions associated with erosion in the underlying reflection, which appears thinner below the pockmarks (Figure 8A). The fill of the pockmarks appears to be mainly draping. Most of the pockmarks within each pockmark field are associated with the upward termination of a high-amplitude pipe.

A few discrete paleopockmarks occur dispersed within the Miocene succession bracketing-focused fluid flow to the seabed at the time of the affected horizons. These pockmarks are commonly related to underlying Miocene turbidite channels or located at the upward termination of high-amplitude pipes.

\section{Fluid-Flow Features in the Pliocene-Pleistocene Succession}

\section{Stacked Paleopockmarks}

The most dominant fluid-flow structure within the polygonally faulted Pliocene-Pleistocene sediments is the abundant occurrence of vertically stacked paleopockmarks located in the central parts of the Pliocene-Pleistocene minibasin depocenters (Figures 2, 9). The stacked paleopockmarks or "bulls-eye" pockmarks as they have been informally named were thoroughly described and analyzed in a previous article (Andresen and Huuse, 2011) and are therefore only briefly described here. The stacked paleopockmarks consist of 1 to 8 distinct pockmarks arranged subvertically above each other with intervening intervals of drape and onlap fill (Figure 9A). The stacks typically measure 50 to $600 \mathrm{~ms}$ TWT in height ( 40-450 m [130-1475 ft]) and are 70 to $500 \mathrm{~m}(230-1640 \mathrm{ft})$ wide. Interestingly, the stacked paleopockmarks occur at the center of the polygonal fault cells (Figure 9B) and not above fault intersections, which is in contrast to pockmark and fault occurrences previously reported from studies to the north of this study area (Gay et al., 2004, 2006a). Two major pockmark formation levels are found within middle and upper Pliocene strata, followed by minor concentrations of pockmarks in the lower Pleistocene successions. The best estimate for the pockmark recurrence interval within the stacks is 0.09 to $0.22 \mathrm{~m}$.y. The formation levels have tentatively been suggested to correlate with sea level falls, thus providing a possible trigger for pockmark formation by lowering the confining pressure in the shallow subsurface (Andresen and Huuse, 2011).

\section{High-Reflectivity Zones and Low-Amplitude Seismic Chimneys}

Another conspicuous feature within the seismic images of the Pliocene-Pleistocene sediments is thick (up to $165 \mathrm{~ms}$ TWT, 140 m [460 ft]) zones of enhanced reflectivity within the polygonally faulted succession (Figures 10A; 11C) (Cunningham and Lindholm, 2000; Gay et al., 2006a; Andresen and Huuse, 2011). In the minibasins, the highreflectivity zones (HRZs) are commonly associated with a BSR located approximately $280 \mathrm{~ms}$ TWT $(\sim 235 \mathrm{~m}[\sim 770 \mathrm{ft}])$ below the seabed (Figure 10A), and hence the HRZs have been interpreted as representing intervals of free gas below the gas-hydrate stability zone (GHSZ) (Cunningham and Lindholm, 2000; Gay et al., 2006a). Above the salt structures, the BSR is typically located shallower, approximately 120 ms TWT $(\sim 100 \mathrm{~m}[\sim 330 \mathrm{ft}])$ below the seabed (Figure 11A). The HRZs are clearly delineated using RMS amplitude displays of the Pliocene-Pleistocene succession (Figure 10B). They typically occur in salt minibasins in close proximity to salt structures or above Miocene structural highs (Figures 10A; 11C). In the northern study area, the HRZs occur obliquely above the distal part (downdip pinch-out) of the pronounced upper Miocene terminal fan system (Figure 10A, B). The HRZs are associated with low-amplitude deeply rooted $(<3 \mathrm{~s}$ TWT $\sim 1 \mathrm{~km}[\sim 0.6 \mathrm{mi}$ ] [below sea floor]) seismic chimneys that commonly cut through the HRZs and terminate in seabed pockmarks, suggesting a bypass of the HRZs and overlying GHSZ from the deeper sections (Figures 10B; 11C). The 
chimneys are most typically found above Miocene structural highs, and the lower parts of the chimneys are commonly characterized by thick and wide zones of acoustic distortion (as much as $2 \mathrm{~km}$ [1.25 mi] wide and $450 \mathrm{~m}$ [1475 ft] tall), resembling gas clouds or wide wipeout zones (Figure 11C) (cf. Cowley and O'Brien, 2000; Løseth et al., 2009). The chimneys also appear as isolated verticalamplitude anomalies and may represent real structures as opposed to near-surface attenuation phenomena resulting from acoustic dimming below high-amplitude anomalies associated with the seabed pockmarks. The nature of these "real" chimneys is still enigmatic as no well-documented outcrop examples or core calibrations are known (cf. Cartwright et al., 2007).

\section{Present-Day Fluid-Flow Features: Seabed Pockmarks}

The Pliocene and lower Pleistocene sediments are overlain by a thin succession $(\sim 100 \mathrm{~m}[\sim 330 \mathrm{ft}])$ of upper Pleistocene to Holocene strata. Presentday (or very recent) fluid-flow features in the seismic data are represented by seabed pockmarks that are abundant on the gently southwestwarddipping seabed in the study area (Figures 2; 11B) and are widespread in the lower Congo Basin (Gay et al., 2007; Pilcher and Argent, 2007). The pockmarks are typically circular and range in size from 70 to $770 \mathrm{~m}(230-2525 \mathrm{ft})$ in diameter and a depth of 10 to $40 \mathrm{~ms}$ TWT $(\sim 8-30 \mathrm{~m} \mathrm{[} \sim 26-98 \mathrm{ft}])$. Generally, the distribution of the seabed pockmarks seems to be controlled by the distribution of salt structures. Typically, the pockmarks occur in clusters above the salt and are commonly related with a BSR, demonstrating their association with methane and possibly higher hydrocarbons (Figure 11A, B). The pockmarks are preferentially located on the updip side of salt diapirs, whereas they are absent on the downdip side of particularly the largest salt structures that are commonly overhanging in a downdip direction (Figures 2; 11B, D). A more random distribution is observed for seabed pockmarks occurring at the inner parts of rafts and above shallow structural highs (i.e., not within the minibasins or above salt structures). Above struc- tural highs, the pockmarks can commonly be associated with low-amplitude deeply rooted chimneys and the HRZs (Figure 11C). Linear arrangements of seabed pockmarks are found above faults, and in the southern salt minibasin, a large linear trend of seabed pockmarks parallels the depocenter axis (Figure 2). These pockmarks constitute the upward termination of Pliocene-Pleistocene paleopockmark stacks and are not linked with a deeper plumbing system (Andresen and Huuse, 2011).

No positive forms such as submarine mud volcanoes and other mound-shaped structures and potential associated feeder conduits have been observed at or below (buried) the sea floor.

\section{DISCUSSION}

\section{Interpretation of the Fluid-Flow Features}

The preceding section outlined the observations pertaining to several types of fluid-flow features and amplitude anomalies detected in the study area. Some of the features are only represented in one of the salt minibasins but most of the features are found in both areas. Generally, for all the types of features described in this study, a fluid-flow origin is anticipated based on the fact that fluids migrating through or being stored within a sedimentary succession and their associated diagenetic features are the most common cause for seismic amplitude anomalies associated with stratally discordant seismic features (Cowley and O'Brien, 2000; Cartwright et al., 2007; Løseth et al., 2009). Lithologic variations including rock type, permeability, porosity, pore pressure and pore-fluid content, opal A to opal CT transformations, and igneous (and clastic) intrusions along with technical aspects such as seismic velocity, tuning effects, source-receiver offset (amplitude variation offset), and other features represent some of the mechanisms that may also cause amplitude anomalies in the sediments and the seismic data (Hilterman, 2001; Cartwright et al., 2007; Davies and Cartwright, 2007).

The various expressions of pockmarks that are interpreted to be caused by expulsion of fluids to the paleo-sea floor (Judd and Hovland, 2007) clearly 
indicate that fluid intermittently vented to the sea floor within the study area from at least the middle Miocene (ca. $12 \mathrm{Ma}$, timing of the pockmark fields) to the present day. This time span correlates to a period where the source rocks in the area, particularly the Iabe Formation, have been modeled to be mature for oil and gas expulsion (Cole et al., 2000; Maersk Oil, 2007, internal data).

Because of the inconsistent amplitude signature at the top of the high-amplitude pipes, the origin of these anomalies is somewhat enigmatic because they are characterized by both soft and hard reflections at their tops. A soft reflection from the pipe tops (positive-amplitude reflection [blue], Figure 7A) could originate from a pipe associated with small accumulations of shallow gas. Many of the pipes appear as stronger anomalies on RMS amplitude extractions from the far stack seismic volume, indicating that there may be fluids within the pipes (Ostrander, 1984; Bacon et al., 2003). A hard origin of the pipe top reflections (negative reflection [red], e.g., Figure 6B) could result from a cementation of the pipe or from concretions within the pipe, both generated in relation to diagenetic transformations of the pipe sediments formed during the passage of fluids and associated microbial activity (Jørgensen and Boetius, 2007). Carbonate concretions related to submarine venting sites have been reported from pockmark interiors by several studies (cf. Judd and Hovland, 2007) and have also been suggested to form within pipes underlying the pockmarks (Hovland et al., 2005). The two types of pipes observed in this study appear to occur equally in the study area, but the finer distribution of hard and soft pipes may be influenced by the nature of the fluid supply, occurrence relative to the GHSZ, lithology, and porosity-permeability of the host sediment. Regardless of their individual controls, based on their spatiotemporal occurrence and relation to underlying focus points, such as structural highs, Miocene fan pinch-outs and Oligocene turbidite channels (Figures 6B; 7), both types of columnar highamplitude reflections (hard or soft pipes) are considered to be related to focused cross-stratal fluid migration. Elsewhere in the lower Congo Basin, turbidite channels have also been correlated with fluid-flow features such as pipes and seabed pockmarks (Gay et al., 2006b). Given the extensive vertical and stratigraphic interval in which the pipes are found, it appears likely that the pipes may represent fluid migration conduits formed as discrete events probably facilitated by hydrofracturing of the sediments because of overpressure buildup from below. A more gradual generation of individual pipes would imply a seeping nature of the fluids responsible for the generation of the pipes, and this Darcy-flow type of fluid migration is probably only significant in permeable (coarse-grained) sediments and relatively insignificant in mudstones. The highamplitude patches have a more strata-parallel geometry and may be more likely to be generated because of lithologic and/or porosity variations in the sediment instead of because of varying fluid contents.

Comparing the high-amplitude pipes (bright) with the seismic chimneys (dim) that are also thought to be generated because of fluid flow (Gay et al., 2006a; Cartwright et al., 2007; Løseth et al., 2009), it is interesting to consider why fluid flow in some cases leaves a bright signature, whereas in others, a dim signature results. From first principles, some general remarks can be made that may help elucidate the bright versus dim character of fluid-flow conduits. When considering the conduits, one may subdivide them into intra-GHSZ and sub-GHSZ conduits; the importance being that below the GHSZ, any gas within the host sediments and the conduits would be free or dissolved, whereas inside the GHSZ, any gas would be frozen in clathrate hydrates, unless part of a rapidly migrating freegas phase inside a focused fluid conduit, bypassing the GHSZ (Hustoft et al. 2009). When evaluating the effects of gas on the acoustic expression of the shallow subsurface, consider that only 5 to $10 \%$ gas saturation will give rise to a velocity decrease of some $30 \%$ for unconsolidated sediments, whereas further gas saturation increases have negligible effects on interval velocities and associated seismic responses (Hilterman 2001). Pipes reported elsewhere (Cartwright et al., 2007; Hustoft et al., 2009; Løseth et al., 2009) have commonly been associated with cemented intervals and enhanced gas hydrate concentrations, both associated with acoustic 
impedance increases, which in addition to the effects of free gas would lead to more extreme acoustic impedance contrasts within the pipes and their vicinity. Although gas hydrate would not be expected beneath the GHSZ, any fluid-flow-related cemented zones could extend deep into the subsurface. Subvertical zones of dimming referred to as chimneys may be caused by the effects of near-surface attenuation effects, for example, because of thick freegas intervals near the surface and/or because of extensive zones of free gas or zones of hydraulic fracturing that may or may not be associated with gas (Cartwright et al. 2007; Løseth et al., 2009). Although the former would give rise to an apparent chimney with limited potential to distinguish any vertically distributed gas or conduits, the latter options would reflect the occurrence of conduits. Hence, in the cases where we do not observe strong reflections above dim chimneys, we infer that they most likely represent zones of near-vertical fracturing, possibly associated with gas migration or diffuse zones of enhanced gas concentrations in the pore space.

\section{Timing and Major Controls on Formation of Fluid-Flow Features}

\section{Timing of the Fluid-Flow Features}

Given the different expressions of the fluid-flow features in the study area, the fluid availability most likely changed through time. The availability of fluids naturally determines whether fluid-flow features will form in the first place and includes parameters such as fluid sources and fluid migration timing. Several different fluid sources may be present within the studied plumbing system and include thermogenic fluids (oil and gas), biogenic fluids (methane), and formation fluids (pore water). The fluid sources for each period (Miocene, Pliocene-Pleistocene, and present day) are discussed further in the next section, whereas fluid migration timing will be addressed here.

The most precise and strongest timing indicators of the fluid-flow features observed in this study are the pockmarks, which bracket the time of fluid flow to the horizon (paleo-sea floor) at which they occur (Judd and Hovland, 2007). Hence, the contemporaneous occurrence of pockmark fields in the middle Miocene of two separate salt minibasins indicates that a large volume of overpressured fluids was being expelled during that time (ca. $12 \mathrm{Ma}$ ) in both basins. Likewise, the present-day pockmarks indicate that fluids are escaping to the sea floor at the present time, whereas the Pliocene-Pleistocene stacked paleopockmarks evidence fluid escape from within the minibasins during that period.

The timing of formation of the high-amplitude pipes, which stratigraphically occur in both deeper and shallower successions than the pockmark fields, is more difficult to establish precisely. A simple relation of relative timing of the pipes might suggest that stratigraphically shallower pipes were formed after the deeper pipes. However, as no crosscutting relations have been observed, it is difficult to verify whether they are upward-younging synchronous pipes without including other evidences. Because most of the pockmarks in the two pockmark fields commonly form the upward termination of highamplitude pipes (Figure 8A), these pipes and the pockmarks possibly formed during the same process and hence have equal timing (ca. $12 \mathrm{Ma}$ ). The present-day amplitude anomalies in the highamplitude pipes is either as previously mentioned a diagenetic feature resulting from a remnant (or more recently) fluid flow or may result from fluids stored within the pipes at the present day. Therefore, the timing of pipes without pockmarks at their upward termination is poorly constrained, and many of the pipes hosted within lower and middle Miocene strata could thus be much younger than $12 \mathrm{Ma}$, although the absence of a crater might also be explained by a less vigorous venting process and/or postevacuation erosion of the sea floor, although we have not seen evidence for the latter.

\section{Structural Controls}

The present-day distribution of seabed pockmarks is strongly influenced by the salt structures, indicating that salt flanks may act as fluid focus areas today, and that salt structures impose a major structural control on the distribution of fluid-flow features in the study area. Likewise, the concentration of high-amplitude pipes above Oligocene 
Figure 13. Illustration of the progressive development of the fluid-flow regime through time in the study area. Black arrows indicate focused fluid migration pathways. The timing of salt migration and structural formation of the Miocene highs are not constrained by this study. The Miocene fluid flow (A) was dominated by stratal migration and vertical leakage of thermogenic fluids sourced from the mature labe Formation since ca. $12 \mathrm{Ma}$, resulting in the formation of the high-amplitude pipes.

Fluid flow was centered above underlying structural highs and Oligocene channels. During the late Miocene (B), terminal fan systems were deposited in the minibasin low areas between salt structures.
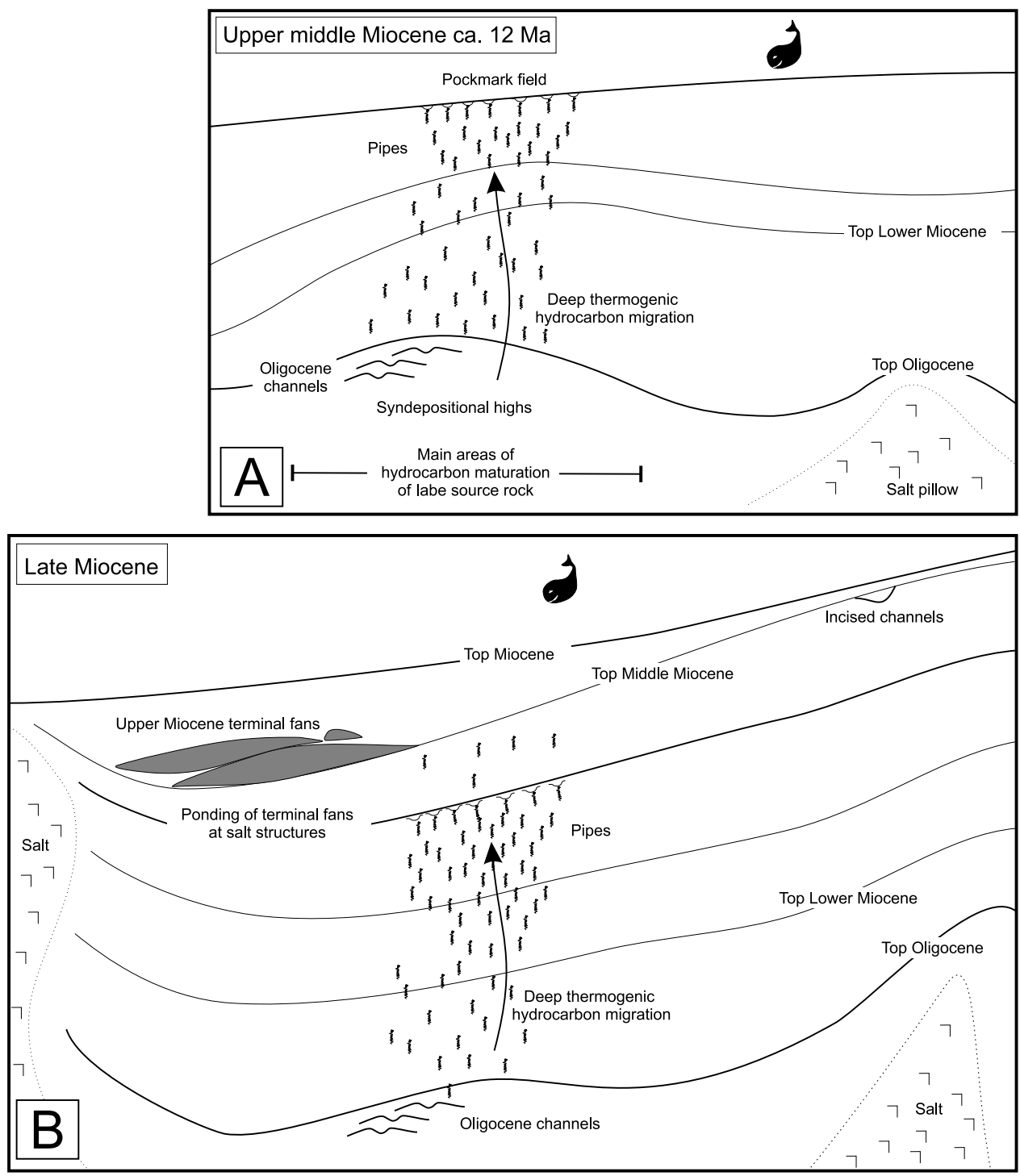

and Miocene syndepositional structural highs suggest that structural controls in general have had a major influence on the fluid-flow features observed. Major faults in the deeper Miocene strata also impose a structural control, where faults operate as compartment separators (sealing) of areas with varying intensities of pipe activity (Figure 7E). In the shallow section (upper Miocene to Holocene) the structural elements in the form of polygonal faults do not seem to influence the vertical fluid flow, as exemplified by the stacked paleopockmarks in the Pliocene-Pleistocene succession, which occur at the center of polygonal fault cells and not at fault intersections. This may be caused either by a lack of sealing or conducting properties of the polygonal faults or simply because the faults formed after the pockmarks as interpreted by Andresen and Huuse (2011). However the polygonal faults do appear to seal laterally in some situations, whereas the HRZs in the minibasins are seen to terminate abruptly at discrete polygonal fault planes (Figure 10A).

\section{Depositional Controls}

Fluid flow in the study area may also be influenced by depositional controls such as lithologic variations, where in particular, the sand/shale ratio of the sediments may provide an important control on fluid flow. For instance, the upper Miocene terminal fans represent a strong lithologic and hydraulic anomaly 

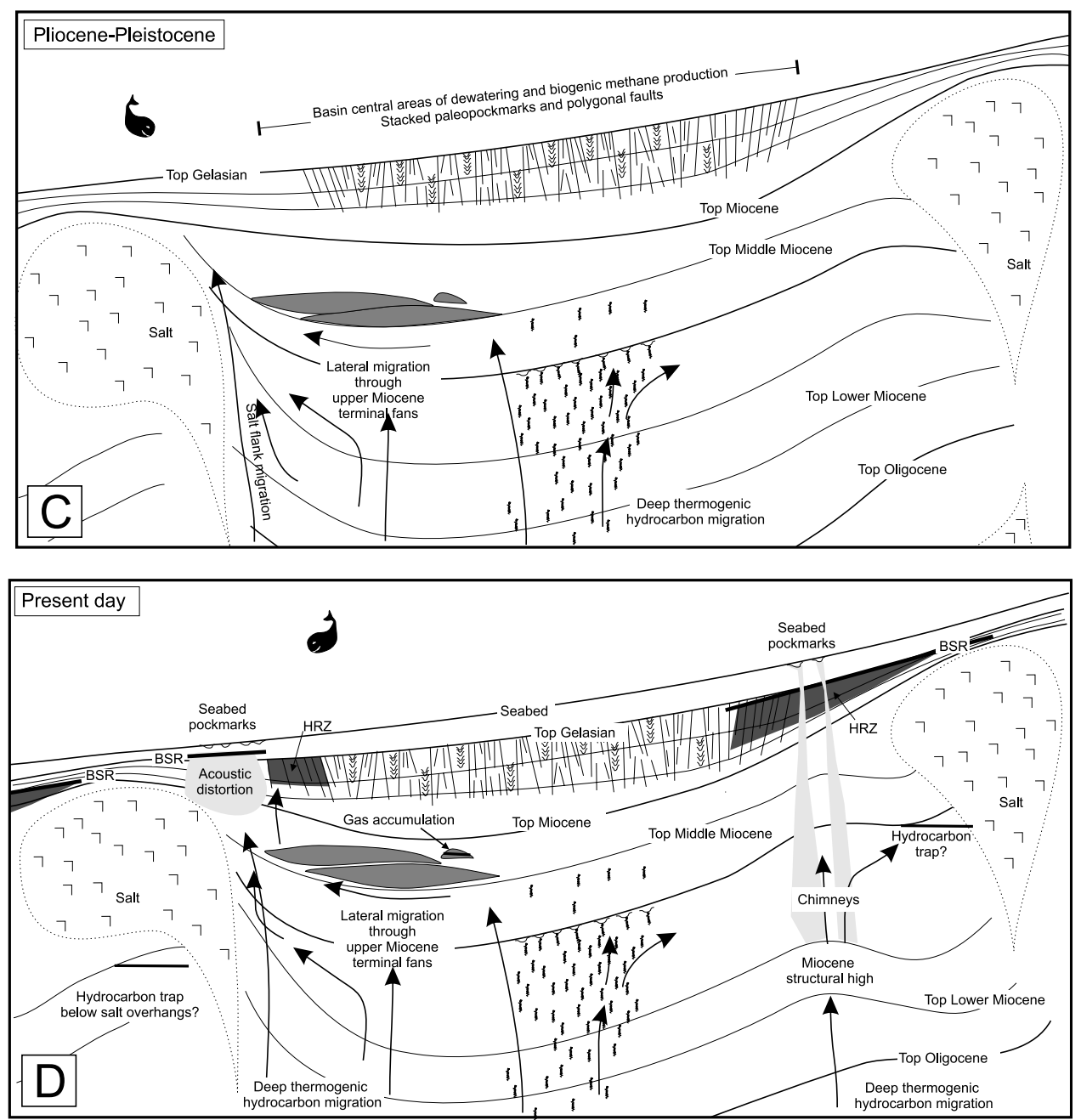

Figure 13. Continued. The Pliocene-Pleistocene fluid flow (C) was dominated by repeated biogenic gas and pore-water expulsion during early burial, resulting in the formation of stacked paleopockmarks in basin central areas. The terminal fan systems facilitated lateral migration of basin central deeper thermogenic fluids to salt flanks and basin margin areas. The present-day fluid regime (D) is dominated by thermogenic fluid escape along salt flank margins, causing seabed pockmarks on the updip side of the salt structures, whereas stratal migration results in a strong lateral transfer of pressure and fluids. In contrast, thermogenic fluids may be trapped downdip beneath salt overhangs. A secondary fluid migration system appears above Miocene structural highs, where seismic chimneys lead directly to seabed pockmarks, bypassing the free-gas and gas-hydrate stability zones. BSR $=$ bottomsimulating reflector; $\mathrm{HC}=$ hydrocarbon; HRZ = high-reflectivity zone. of sand-rich intervals in the otherwise mudstonedominated sediments, and this may have influenced the fluid migration pattern in the area. The repeated pockmark formation in the Pliocene-Pleistocene succession (the stacked paleopockmarks) is confined to the basin central areas, and pockmark formation may have been mostly controlled by the composition of the depocenter sediments (Andresen and Huuse, 2011). Like some of the high-amplitude pipes isolated, discrete pockmarks in the middle and lower Miocene successions are also commonly found above turbiditic channels, indicating that fluids were temporarily stored within or at least leaking from such probably sand-rich channels.

In summary, the observed fluid-flow features in the study area tend to be controlled by (1) availability of fluids including fluid source and fluid migration timing, (2) structural controls primarily constituted by the salt structures and underlying structural highs, and (3) depositional controls, for instance imposed by turbidite channels and the upper Miocene terminal fan systems and minibasin dewatering and degassing of biogenic methane.

\section{Characterization of the Fluid-Flow Regime through Time}

The diversity of fluid-flow features observed in this study probably results from a diversity of flows originated in varying fluid sources. Because the different types of fluid-flow features seem to apply mostly to certain stratigraphic intervals, that is, the high-amplitude pipes are confined to the Miocene strata, the stacked paleopockmarks to the PliocenePleistocene strata, this may indicate that the study area underwent a progression of fluid-flow regimes 
through time. During this development, the relative importance of the three major controls, fluid availability, and structural and depositional control, varied to produce different settings for the fluid-flow migration and resulted in the complex composition of fluid-flow features we observe today. The development of the plumbing system from the Miocene to the present day is summarized in Figures 12 and 13. The study area is one of active fluid migration since the middle Miocene, and no sign exists that the activity is abating, thus indicating that fluids are still being supplied from at least some of the regional source rocks.

\section{Miocene Fluid-Flow Regime}

The Miocene fluid-flow regime (Figures 12, 13A) represented by the high-amplitude pipes and the distinct pockmark fields has the character of an extensive and consistent migration of fluids through the sediments. The fluid-flow anomalies occur widespread both laterally and stratigraphically in the Miocene succession but tend to be focused above deeper syndepositional highs, Oligocene channels, and deep-rooted faults (Figure 7C, D). Such areas may be characterized as primary regions of fluid escape during prolonged periods within the Miocene. The concentration of anomalies above the syndepositional highs in the area suggests that the Miocene fluid flow probably was dominated by migration down flank from the highs (stratally from basins to highs via aquifers) and that fluid migration from the highs was mainly vertical. The subtle correlation with underlying Oligocene channels might suggest that fluids were temporarily focused in the channels, leading to a higher concentration of fluid-flow features above as seen elsewhere in the region (Gay et al., 2007; Pilcher and Argent, 2007). As indicated by the pockmark fields, the migration of fluids from reservoir to surface happened from at least the middle Miocene (ca. $12 \mathrm{Ma}$ ). Furthermore, the timing of the pockmark fields implies that fluid expulsion happened synchronously in the two adjacent salt minibasins. The above considerations could be met by a thermogenic fluid source stratigraphically common for the two salt minibasins. The main source rock in the study area is the mature Upper Cretaceous Iabe
Formation, which has been deposited in most of the area covered by this study (Maersk Oil, 2007, internal data). The source rock began expulsion of oil and gas during the mid-Miocene (ca. $15 \mathrm{Ma}$ ) and hence could constitute a potential fluid source (Cole et al., 2000). Thermogenic fluid migration from deeper Upper Cretaceous source kitchens would also naturally be funneled into Oligocene and Miocene syndepositional highs on their way to the surface, resulting in an increased density of fluidflow features in these areas. The synchronous timing of the pockmark fields indicates that the two minibasins went through similar thermal burials and source rock maturations. Thus, other nearby minibasins might also be expected to have followed the same development, and similar fluid-flow features and pockmark fields should thus be expected elsewhere in this region.

During the latest part of the Miocene (Figures 12; 13B), the terminal fan systems (Figure 6) were deposited in the northern minibasin, imposing a drastic change in lithology and hydraulic heterogeneity. The coarser grained terminal fans may have acted as aquifers and lateral carrier beds, whereby basin central fluids (migrated vertically through the lower and middle Miocene strata) may have been directed to minibasin margins and/or salt flanks, where they would be conducted farther to the surface (Figure 12). In addition, the HRZs observed in the Pliocene-Pleistocene succession also tend to be located above the distal parts of the terminal fans (Figure 10A, B), which may indicate that fluids are presently seeping out of the fans and into the Pliocene-Pleistocene free-gas zone.

The Miocene fluid-flow regime is interpreted to be dominated by thermogenic fluids sourced primarily by the Iabe Formation. The pockmark fields that were generated ca. $12 \mathrm{Ma}$ probably represent some of the oldest fluid-flow features in the study area, although some of the high-amplitude pipes below the fields may have been generated previously. Underlying structural highs controlled the mainly vertical migration pathways (kilometer scale) and the distribution of fluid-flow features in the lower and middle Miocene strata. During the end of the Miocene, depositional controls may have been more apparent than structural controls, adding a 
lateral (stratal) component to the fluid migration system, leading the fluids to the minibasin margins.

\section{Pliocene-Pleistocene Fluid-Flow Regime}

The Pliocene-Pleistocene fluid-flow features, the stacked paleopockmarks, are mainly found within the central parts of the Pliocene-Pleistocene depocenters. Andresen and Huuse (2011) argued that the stacked paleopockmarks were most likely formed by combined biogenic gas and pore-water expulsion from the Pliocene-Pleistocene minibasin sediments, and therefore under the influence of a strong depositional (sedimentologic) and early diagenetic control. The combined water and methane expulsion was produced because of a combination of early stage compaction of the fine-grained clay-rich sediments, leading to excessive volume loss and pore-water expulsion and an enhanced biogenic methane production during the middle and late Pliocene, as a result of increased deposition of organic matter caused by increased organic matter productivity induced by the Benguela upwelling current from the latest Miocene onward (Emery and Uchupi, 1984; Berger et al., 2002).

Thus, the minibasin-centered Pliocene-Pleistocene fluid-flow regime (Figure 13C) is interpreted to be dominated by short-distance vertical migration and expulsion of biogenic methane and pore water and to be highly influenced by depositional controls, that is, the Pliocene-Pleistocene minibasin sedimentation (Andresen and Huuse, 2011). Thermogenic fluid migration most likely also occurred during the Pliocene-Pleistocene but was probably concentrated at minibasin margins instead of the basin centers because of the growing salt structures that caused the Miocene strata to deform updip against the salt flanks that in turn affected the fluid migration from the deeper sections. In some areas, lateral carrier beds such as the upper Miocene terminal fans in the northern minibasin enhanced the margin-directed flow of deeper thermogenic fluids during the Pliocene-Pleistocene (Figures 12; 13C).

\section{Present-Day Fluid-Flow Regime}

The present-day fluid flow (Figure 13D), exemplified by the seabed pockmarks (Figures 2, 11), is concentrated at salt structures and basin margins and lacks any basin central anomalies and is thus directly opposite the Pliocene-Pleistocene fluidflow regime. This implies a shift in fluid source, and the concentration of pockmarks above the salt structures indicates that the present-day source might be related to a combination of stratal and focused fluid migration along the salt flanks. As inferred previously, deep thermogenic fluid migration is likely to have been directed to the minibasin margins during the late Miocene and Pliocene, and hence the present-day fluid regime is also likely dominated by thermogenic fluids. The seabed pockmarks consistently occur at the updip side of the larger salt structures, whereas they are absent from the downdip sides that are commonly overhanging (Figure 11D). This might indicate that deep thermogenic fluids that migrated to the salt flanks at the landward side of the minibasins may now be trapped below the salt overhangs. As an example, the salt-diapir overhang seen in Figure 11D is about $4 \mathrm{~km}$ ( $2.5 \mathrm{mi}$ ) wide in the downdip direction and about $10 \mathrm{~km}(\sim 6.2 \mathrm{mi})$ wide at its widest, with a roughly triangular plan form (Figure 11B). The resulting area of overhang is thus about $4 \times$ $10 \mathrm{~km}$ by $0.5=20 \mathrm{~km}^{2}\left(7.5 \mathrm{mi}^{2}\right)$. Given an updip salt seal, such a trap could hold large column heights of perhaps hundreds of meters. The seismic sections do suggest that the lower Miocene and Oligocene is dipping up toward the salt overhang, thus potentially forming a perfect trap (Figure 11D). Assuming a (conservative) 100-m (330-ft) column and $25 \%$ porosity, fluid volumes in this trap could be on the order of $0.5 \mathrm{~km}^{3}\left(\sim 300 \times 10^{6}\right.$ barrels $)$, although of course, such estimates are hugely uncertain and difficult to verify using surface geophysical methods in the absence of a wellbore.

Other seabed pockmarks occur above Miocene structural highs, where HRZs and chimneys also appear. These pockmarks are located away from the salt structures but within the basin margin areas. The relation between the chimneys and the seabed pockmarks suggests that the HRZs and the GHSZs are currently bypassed by deep fluids migrated through the Miocene structural highs, leading directly to the seabed and the pockmarks. Such a system represents an alternative route for the presentday fluid flow that bypasses the salt flank migration 
system. Besides being correlated to Miocene highs, the HRZs occasionally occur obliquely above the downdip pinch-out of deeper carrier beds, such as the upper Miocene terminal fans in the northern minibasin. This might indicate that fluids are presently leaking out of the terminal fans and that the present day gas-hydrate and the free gas (HRZs) below the BSRs are related to the thermogenic migration system and thus are caused by thermogenic gas residing in the shallow sediments.

To summarize, the present-day fluid-flow regime is thought to be dominated by thermogenic hydrocarbons and mostly structurally controlled by salt flank-related migration on a kilometer scale. Importantly, our observations suggest that salt overhangs may act as large and efficient fluid traps, although this concept still needs to be verified in this area. Sand-rich intervals in the Miocene enhance the salt flank migration route by facilitating lateral migration from the basin central areas. The salt flank migration system is intersected at Miocene structural highs where fluid-flow conduits (seismic chimneys) lead directly to seabed pockmarks and hence bypass the HRZ and the GHSZ, possibly allowing the sampling of deep thermogenic fluids at the sea floor.

\section{CONCLUSIONS}

Careful analysis of 3-D seismic data has revealed the occurrence of several different types of fluidflow features in the overburden succession (Miocene to Holocene) offshore Angola. The main types of fluid-flow features include different pockmark types, high-amplitude pipes, HRZs, and lowamplitude vertically extensive seismic chimneys. The high-amplitude pipes generally occur in the lower and middle Miocene successions and represent shallow gas accumulations and/or diagenetic features associated with fluid flow through the sediments. The different pockmark types include discrete paleopockmarks, paleopockmark fields, stacked paleopockmarks, and seabed pockmarks. The discrete paleopockmarks are commonly seen as the upward termination of the high-amplitude pipes or in relation with Miocene turbidite channels. The two large pockmark fields are observed at an upper middle Miocene horizon dated as ca. $12 \mathrm{Ma}$, evidencing a multibasin fluid expulsion event at this time, which may apply equally to other salt minibasins in the lower Congo Basin. The stacked paleopockmarks occur within Pliocene-Pleistocene sediments and are related to minibasin degassing and dewatering before polygonal faulting. The seabed pockmarks are associated mainly to salt structures and secondarily to Miocene structural highs, where focusing of fluids from particularly the deeper section is facilitated. The lack of seabed pockmarks above the downdip overhanging parts of salt structures may indicate a potential occurrence of large shielded traps below the overhangs.

The spatiotemporal occurrence and detailed characteristics of fluid-flow features in the seismic data reveal that the hydrocarbon plumbing system commenced at ca. $12 \mathrm{Ma}$, roughly coinciding with predictions of source rock expulsion timing from petroleum systems modeling. The area experienced fluid-flow activity intermittently to the present day. During this time interval, the system went through three stages of fluid-flow regime as follows:

- The Miocene fluid-flow regime was characterized by thermogenic fluid flow concentrated above syndepositional structural highs and Oligocene channels.

- The Pliocene-Pleistocene fluid flow was mainly controlled by depositional factors and was dominated by biogenic methane and pore-water expulsion during early stage burial and diagenesis of the depocenter sediments.

- The present-day fluid regime is mostly influenced by structural controls imposed by the salt structures and interpreted to be dominated by thermogenic fluids. The primary fluid migration system is concentrated along the salt flanks and minibasin margins, whereas a secondary system is generated above Miocene structural highs where seismic chimneys lead directly to seabed pockmarks. Upper Miocene carrier beds enhance the basin margin fluid direction by allowing lateral (stratal) migration of fluids from basin central areas to the margins and the salt flanks. 
The main controls on fluid-flow activity in the study area are mature source rock availability; distribution and evolution of salt structures, aquifers and seals; and associated migration and trapping configurations, biogenic methane generation, and dewatering of minibasin sediments.

\section{REFERENCES CITED}

Anderson, J. E., J. Cartwright, S. J. Drysdall, and N. Vivian, 2000, Controls on turbidite sand deposition during gravitydriven extension of a passive margin: Examples from Miocene sediments in Block 4, Angola: Marine and Petroleum Geology, v. 17, p. 1165-1203, doi:10.1016 /S0264-8172(00)00059-3.

Andresen, K. J., and M. Huuse, 2011, "Bulls-eye" pockmarks and polygonal faulting in the lower Congo Basin: Relative timing and implications for fluid expulsion during shallow burial: Marine Geology, v. 279, p. 111-127, doi:10.1016/j.margeo.2010.10.016.

Andresen, K. J., M. Huuse, and O. R. Clausen, 2008, Morphology and distribution of Oligocene and Miocene pockmarks in the Danish North Sea: Implications for bottom current activity and fluid migration: Basin Research, v. 20, p. 445-466, doi:10.1111/j.1365-2117 .2008.00362.x.

Anka, Z., M. Seranne, M. Lopez, M. Scheck-Wenderoth, and B. Savoye, 2009, The long-term evolution of the Congo deep-sea fan: A basin-wide view of the interaction between a giant submarine fan and a mature passive margin (ZaiAngo project): Tectonophysics, v. 470, p. 4256, doi:10.1016/j.tecto.2008.04.009.

Bacon, M., R. Simm, and T. Redshaw, 2003, 3-D seismic interpretation: Cambridge, Cambridge University Press, 208 p.

Bartek, L. R., P. R. Vail, J. B. Anderson, P. A. Emmet, and S. Wu, 1991, Effect of Cenozoic ice sheet fluctuations in Antarctica on the stratigraphic signature of the Neogene: Journal of Geophysical Research, v. 96, no. B4, p. 67536778, doi:10.1029/90JB02528.

Berger, W. H., C. B. Lange, and G. Wefer, 2002, Upwelling history of the Benguela-Namibia system: A synthesis of Leg 175 results, in G. Wefer, W. H. Berger, and C. Richter, eds., ODP Proceedings, Scientific Results: College Station, Texas, Ocean Drilling Program, v. 175, p. 1-103.

Berndt, C., 2005, Focused fluid flow in passive continental margins: Philosophical Transactions of the Royal Society A, v. 363, p. 2855-2871, doi:10.1098/rsta.2005.1666.

Bolli, H. M., and W. B. F. Ryan et al., 1978, Initial reports of the deep sea drilling project: Washington, DC, U.S. Government Printing Office, v. 40, chapter 4, p. 357-455.

Brice, S. E., M. D. Cochran, G. Pardo, and A. D. Edwards, 1982, Tectonics and sedimentation of the South Atlantic rift sequences: Cabinda, Angola: AAPG Memoir 34, p. $5-18$.

Broucke, O., F. Temple, D. Rouby, C. Robin, S. Calassou, T.
Nalpas, and F. Guillocheau, 2004, The role of deformation processes on the geometry of mud-dominated turbiditic systems, Oligocene and lower-middle Miocene of the lower Congo Basin (west African margin): Marine and Petroleum Geology, v. 21, p. 327-348, doi:10 .1016/j.marpetgeo.2003.11.013.

Burwood, R., 1999, Angola: Source rock control for the Lower Congo coastal and Kwanza Basin petroleum systems, in N. R. Cameron, R. H. Bate, and V. S. Clure, eds., The oil and gas habitats of the South Atlantic: Geological Society (London) Special Publication 153, p. 181-194.

Burwood, R., P. J. Cornet, L. Jacobs, and J. Paulet, 1990, Organofacies variation control on hydrocarbon generation: A Lower Congo coastal basin (Angola) case history: Organic Geochemistry, v. 16, no. 1-3, p. 325-338, doi:10.1016/0146-6380(90)90052-2.

Cartwright, J., and M. Huuse, 2005, 3-D seismic technology: The geological "Hubble": Basin Research, v. 17, p. 1-20, doi:10.1111/j.1365-2117.2005.00252.x.

Cartwright, J. A., M. Huuse, and A. Aplin, 2007, Seal bypass systems: AAPG Bulletin, v. 91, p. 1141-1166, doi:10 .1306/04090705181.

Cole, G. A., A. G. Requejo, D. Ormerod, Z. Yu, and A. Clifford, 2000, Petroleum geochemical assessment of the lower Congo Basin, in M. R. Mello and B. J. Katz, eds., Petroleum systems of South Atlantic margins: AAPG Memoir 73, p. 325-339.

Cowley, R., and G. W. O'Brien, 2000, Identification and interpretation of leaking hydrocarbons using seismic data: A comparative montage of examples from the major fields in Australia's northwest shelf and Gippsland Basin: Australian Petroleum Production and Exploration Association Journal, v. 40, p. 121-150.

Cunningham, R., and R. M. Lindholm, 2000, Seismic evidence for widespread gas-hydrate formation, offshore west Africa, in M. R. Mello and B. J. Katz, eds., Petroleum systems of South Atlantic margins: AAPG Memoir 73, p. 93-105.

Davies, R. J., and J. A. Cartwright, 2007, Kilometer-scale chemical reaction boundary patterns and deformation in sedimentary rocks: Earth and Planetary Science Letters, v. 262, p. 125-137, doi:10.1016/j.eps1.2007.07.042.

Davies, R. J., S. A. Stewart, J. A. Cartwright, M. Lappin, R. Johnston, S. I. Fraser, and A. R. Brown, 2004, 3-D seismic technology: Are we realizing its full potential?, in R. J. Davies, J. A. Cartwright, S. A. Stewart, M. Lappin, and J. R. Underhill, eds., 3-D seismic technology: Application to the exploration of sedimentary basins: Geological Society (London) Memoir 29, p. 1-9.

Droz, L., F. Rigaut, P. Cochonat, and R. Tofani, 1996, Morphology and recent evolution of the Zaire turbidite system (Gulf of Guinea): Geological Society of America Bulletin, v. 108, p. 253-269, doi:10.1130/0016-7606 (1996) 108<0253:MAREOT>2.3.CO;2.

Duval, B., C. Cramez, and M. P. A. Jackson, 1992, Raft tectonics in the Kwanza Basin, Angola: Marine and Petroleum Geology, v. 9, p. 389-404, doi:10.1016/02648172(92)90050-O.

Emery, K. O., and E. Uchupi, 1984, The geology of the Atlantic Ocean: New York, Springer, 925 p. 
Fort, X., J. P. Brun, and F. Chauvel, 2004, Contraction induced by block rotation above salt (Angolan margin): Marine and Petroleum Geology, v. 21, p. 1281-1294, doi:10.1016/j.marpetgeo.2004.09.006.

Gay, A., M. Lopez, P. Cochonat, and G. Sermondadaz, 2004, Polygonal fault-furrows system related to early stages of compaction: Upper Miocene to recent sediments of the lower Congo Basin: Basin Research, v. 16, p. 101-116, doi:10.1111/j.1365-2117.2003.00224.x.

Gay, A., M. Lopez, P. Cochonat, M. Séranne, D. Levache, and G. Sermondadaz, 2006a, Isolated sea floor pockmarks linked to BSRs, fluid chimneys, polygonal faults and stacked Oligocene-Miocene turbiditic paleochannels in the lower Congo Basin: Marine Geology, v. 226, p. 25-40, doi:10.1016/j.margeo.2005.09.018.

Gay, A., M. Lopez, P. Cochonat, D. Levaché, G. Sermondadaz, and M. Seranne, 2006b, Evidences for early to late fluid migration from an upper Miocene turbiditic channel revealed by 3-D seismic coupled to geochemical sampling within sea floor pockmarks, lower Congo Basin: Marine and Petroleum Geology, v. 23, p. 387-399, doi:10.1016 /j.marpetgeo.2006.02.004.

Gay, A., M. Lopez, C. Berndt, and M. Séranne, 2007, Geological controls on focused fluid flow associated with sea floor seeps in the lower Congo Basin: Marine Geology, v. 244, p. 68-92, doi:10.1016/j.margeo.2007.06.003.

Haq, B. U., J. Hardenbol, and P. R. Vail, 1987, Chronology of fluctuating sea levels since the Triassic: Science, v. 235, p. 1156-1167, doi:10.1126/science.235.4793.1156.

Heggland, R., 1997, Detection of gas migration from a deep source by the use of exploration 3-D seismic data: Marine Geology, v. 137, p. 41-47, doi:10.1016/S0025 -3227(96)00077-1.

Hesthammer, J., A. Stefatos, M. Boulaenko, S. Fanavoll, and J. Danielsen, 2010, CSEM performance in light of well results: The Leading Edge, v. 29, p. 34-41, doi:10.1190 /1.3284051.

Hilterman, F. J., 2001, Seismic amplitude interpretation: Society of Exploration Geophysicists/European Association of Geoscientists and Engineers distinguished instructor course, distinguished instructor series no. 4, SEG/EAGE, 236 p.

Hovland, M., H. Svensen, C. F. Forsberg, H. Johansen, C. Fichler, J. H. Fosså, R. Jonsson, and H. Rueslåtten, 2005, Complex pockmarks with carbonate-ridges off mid-Norway: Products of sediment degassing: Marine Geology, v. 218, p. 191-206, doi:10.1016/j.margeo 2005.04.005.

Hustoft, S., S. Bünz, J. Meinert, and S. Chand, 2009, Gas hydrate reservoir and active methane-venting province in sediments on $<20 \mathrm{Ma}$ young oceanic crust in the Fram Strait, offshore NW Svalbard: Earth and Planetary Science Letters, v. 284, no. 1-2, p. 12-24, doi:10.1016 /j.eps1.2009.03.038.

Huuse, M., C. A.-L. Jackson, P. Van Rensbergen, R. J. Davies, P. B. Flemings, and R. J. Dixon, 2010, Subsurface sediment remobilization and fluid flow in sedimentary basins: An overview: Basin Research, v. 22, no. 4, p. 342360, doi:10.1111/j.1365-2117.2010.00488.x.

Jansen, J. H. F., P. Giresse, and G. Moguedet, 1984, Structur- al and sedimentary geology of the Congo and southern Gabon continental shelf, a seismic and acoustic reflection survey: Netherlands Journal of Sea Research, v. 17, no. 2-4, p. 364-384, doi:10.1016/0077-7579(84) 90056-5.

Jørgensen, B. B., and A. Boetius, 2007, Feast and famine: Microbial life in the deep sea bed: Nature Reviews of Microbiology, v. 5, p. 770-781, doi:10.1038/nrmicro1745.

Judd, A. G., and M. Hovland, 2007, Seabed fluid flow: The impact on geology, biology and the marine environment: New York, Cambridge University Press, 441 p.

Lavier, L. L., M. S. Steckler, and F. Brigaud, 2001, Climatic and tectonic control on the Cenozoic evolution of the west African margin: Marine Geology, v. 178, p. 6380, doi:10.1016/S0025-3227(01)00175-X.

Liro, L. M., and R. Coen, 1995, Salt deformation history and postsalt structural trends, offshore southern Gabon, west Africa, in M. P. A. Jackson, D. G. Roberts, and S. Snelson, eds., Salt tectonics: A global perspective: AAPG Memoir 65, p. 323-331.

Liu, J. P., X. Pan, J. Ma, Z. Tian, Y. Chen, and L. Wan, 2008, Petroleum geology and resources in west Africa: An overview: Petroleum Exploration and Development, v. 35, no. 3, p. 378-384, doi:10.1016/S1876-3804(08) 60086-5.

Lundin, E. R., 1992, Thin-skinned extensional tectonics on a salt detachment, northern Kwanza Basin, Angola: Marine and Petroleum Geology, v. 9, p. 405-411, doi:10 .1016/0264-8172(92)90051-F.

Løseth, H., M. Gading, and L. Wensaas, 2009, Hydrocarbon leakage on seismic data: Marine and Petroleum Geology, v. 26, p. 1304-1319, doi:10.1016/j.marpetgeo.2008 .09 .008

Magoon, L. B., and W. G. Dow, 1994, The petroleum system, in L. B. Magoon and W. G. Dow, eds., The petroleum system: From source to trap: AAPG Memoir 60, p. 3-24.

Marton, L. G., G. C. Tari, and C. T. Lehmann, 2000, Evolution of the Angolan passive margin, west Africa, with emphasis on post-salt structural style, in W. Mohriak and M. Talwani, eds., Atlantic rifts and continental margins: American Geophysical Union, Geophysical monograph series 115, p. 129-149.

O’Brien, G. W., G. M. Lawrence, A. K. Williams, K. Glenn, A. G. Barrett, M. Lech, D. S. Edwards, R. Cowley, C. J. Boreham, and R. E. Summons, 2005, Yampi Shelf, Browse Basin, north-west shelf, Australia: A test-bed for constraining hydrocarbon migration and seepage rates using combinations of 2-D and 3-D seismic data and multiple, independent remote sensing technologies: Marine and Petroleum Geology, v. 22, p. 517-549, doi:10.1016/j.marpetgeo.2004.10.027.

Ostrander, W. J., 1984, Plane-wave reflection coefficients for gas sands at non-normal angles of incidence: Geophysics, v. 49, p. 1637-1648, doi:10.1190/1.1441571.

Pilcher, R., and J. Argent, 2007, Mega-pockmarks and linear pockmark trains on the west African continental margin: Marine Geology, v. 244, p. 15-32, doi:10.1016/j.margeo .2007.05.002.

Pufahl, P. K., M. A. Maslin, L. Anderson, V. Brüchert, F. Jansen, H. Lin, M. Perez, L. Vidal, and Shipboard Scientific Party, 
1998, Lithostratigraphic summary for Leg 175: AngolaBenguela upwelling system, in G. Wefer, W. H. Berger, and C. Richter et al., eds., ODP Proceedings, Initial Reports: College Station, Texas, Ocean Drilling Program, v. 175 , p. $533-542$.

Rouby, D., S. Raillard, F.Guillocheau, R. Bouroullec, and T. Nalpas, 2002, Kinematics of a growth fault/raft system on the west African margin using 3-D restoration: Journal of Structural Geology, v. 24, p. 783-796, doi:10 .1016/S0191-8141(01)00108-0.

Rutherford, S. R., and R. H. Williams, 1989, Amplitudeversus-offset variations in gas sands: Geophysics, v. 54, p. 680-688, doi:10.1190/1.1442696.

Seranne, M., 1999, Early Oligocene stratigraphic turnover on the west Africa continental margin: A signature of the Tertiary greenhouse-to-icehouse transition?: Terra Nova, v. 11, p. 135-140, doi:10.1046/j.1365-3121.1999 .00246.x.

Seranne, M., M. Seguret, and M. Fauchier, 1992, Seismic super-units and post-rift evolution of the continental passive margin of southern Gabon: Bulletin de la Societe Géologique de France, v. 163, no. 2, p. 135-146.

Sikkema, W., and K. M. Wojcik, 2000, 3-D visualization of turbidite systems, lower Congo Basin, offshore Angola, in P. Weimer, R. M. Slatt, J. Coleman, N. C. Rosen, H. Nelson, A. H. Bouma, M. J. Styzen, and D. T. Lawrence, eds., Deep-water reservoirs of the world, Gulf Coast Section-SEPM Foundation, 20th Annual Bob F. Perkins Research Conference, p. 928-939.

Uchupi, E., 1992, Angola Basin: Geohistory and construction of the continental rise, in C. W. Poag and P. C. de Graciansky, eds., Geologic evolution of Atlantic continental rises: New York, Van Nostrand Reinhold, p. 7799.

Uenzelmann-Neben, G., 1998, Neogene sedimentation history of the Congo Fan: Marine and Petroleum Geology, v. 15, p. 635-650, doi:10.1016/S0264-8172(98)00034-8.

Valle, P. J., J. G. Gjelberg, and W. Helland-Hansen, 2001, Tectonostratigraphic development in the eastern lower Congo Basin, offshore Angola, west Africa: Marine and Petroleum Geology, v. 18, p. 909-927, doi:10.1016 /S0264-8172(01)00036-8.

Zachos, J., M. Pagani, L. Sloan, E. Thomas, and K. Billups, 2001, Trends, rhythms, and aberrations in global climate 65 Ma to present: Science, v. 292, p. 686-693, doi:10 .1126/science. 1059412 . 